\title{
Overview of the O3M SAF GOME-2 operational atmospheric composition and $U V$ radiation data products and data availability
}

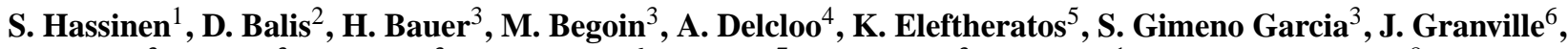 \\ M. Grossi ${ }^{3}$, N. Hao ${ }^{3}$, P. Hedelt ${ }^{3}$, F. Hendrick ${ }^{6}$, M. Hess ${ }^{7}$, K.-P. Heue ${ }^{3}$, J. Hovila ${ }^{1}$, H. Jønch-Sørensen ${ }^{8}$, N. Kalakoski ${ }^{1}$,

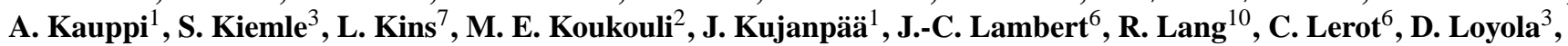 \\ M. Pedergnana ${ }^{3}$, G. Pinardi ${ }^{6}$, F. Romahn ${ }^{3}$, M. van Roozendael ${ }^{6}$, R. Lutz $^{3}$, I. De Smedt ${ }^{6}$, P. Stammes ${ }^{9}$, W. Steinbrecht ${ }^{7}$, \\ J. Tamminen ${ }^{1}$, N. Theys ${ }^{6}$, L. G. Tilstra ${ }^{9}$, O. N. E. Tuinder ${ }^{9}$, P. Valks ${ }^{3}$, C. Zerefos ${ }^{5}$, W. Zimmer ${ }^{3}$, and I. Zyrichidou ${ }^{2}$ \\ ${ }^{1}$ Finnish Meteorological Institute, Helsinki, Finland \\ ${ }^{2}$ Aristotle University of Thessaloniki, Thessaloniki, Greece \\ ${ }^{3}$ Deutsches Zentrum für Luft- und Raumfahrt, DLR, Oberpfaffenhofen, Germany \\ ${ }^{4}$ Royal Meteorological Institute, Brussels, Belgium \\ ${ }^{5}$ Mariolopoulos - Kanaginis Foundation, Athens, Greece \\ ${ }^{6}$ Belgian Institute for Space Aeronomy, BIRA-IASB, Brussels, Belgium \\ ${ }^{7}$ German Weather Service, Offenbach, Germany \\ ${ }^{8}$ Danish Meteorological Institute, Copenhagen, Denmark \\ ${ }^{9}$ Royal Netherlands Meteorological Institute, De Bilt, the Netherlands \\ ${ }^{10}$ EUMETSAT, Darmstadt, Germany
}

Correspondence to: S. Hassinen (seppo.hassinen@fmi.fi)

Received: 29 April 2015 - Published in Atmos. Meas. Tech. Discuss.: 9 July 2015

Revised: 20 December 2015 - Accepted: 5 January 2016 - Published: 8 February 2016

\begin{abstract}
The three Global Ozone Monitoring Experiment2 instruments will provide unique and long data sets for atmospheric research and applications. The complete time period will be 2007-2022, including the period of ozone depletion as well as the beginning of ozone layer recovery. Besides ozone chemistry, the GOME-2 (Global Ozone Monitoring Experiment-2) products are important e.g. for air quality studies, climate modelling, policy monitoring and hazard warnings. The heritage for GOME-2 is in the ERS/GOME and Envisat/SCIAMACHY instruments. The current Level 2 (L2) data cover a wide range of products such as ozone and minor trace gas columns $\left(\mathrm{NO}_{2}, \mathrm{BrO}, \mathrm{HCHO}, \mathrm{H}_{2} \mathrm{O}, \mathrm{SO}_{2}\right)$, vertical ozone profiles in high and low spatial resolution, absorbing aerosol indices, surface Lambertian-equivalent reflectivity database, clear-sky and cloud-corrected UV indices and surface UV fields with different weightings and photolysis rates. The Satellite Application Facility on Ozone and Atmospheric Chemistry Monitoring (O3M SAF) processes and disseminates data 24/7. Data quality is guaranteed by the detailed review processes for the algorithms, validation of the
\end{abstract}

products as well as by a continuous quality monitoring of the products and processing. This paper provides an overview of the O3M SAF project background, current status and future plans for the utilisation of the GOME-2 data. An important focus is the provision of summaries of the GOME-2 products including product principles and validation examples together with sample images. Furthermore, this paper collects references to the detailed product algorithm and validation papers.

\section{Introduction}

Anthropogenic emissions change the composition and chemistry of the atmosphere which, in turn, have an effect on dynamics. These changes are the primary reasons for global climate warming, air pollution and ozone loss. All these effects have a major impact on the living conditions on the Earth. Understanding the evolution of atmospheric composition as well as the coupling between climate and chemistry is a chal- 
lenge which requires an efficient global monitoring system of ozone and other trace gases, ultraviolet radiation, primary pollutants and pre-cursors, together with the distribution and properties of aerosols. With recent volcanic eruptions posing hazards and economic losses to the European aviation business, detection of volcanic sulfur dioxide and aerosols from satellites has become an integral part of the remote sensing of the atmosphere. Satellite-based observations form an important part of this global observing system as they can provide global, three-dimensional coverage with a regular repeat cycle. In this context, essential climate variables have been identified by the Global Climate Observing System (GCOS, 2015) and include, in the atmospheric composition domain, water vapour, anthropogenic greenhouse gases, ozone and its precursors as well as aerosols and its precursors. The strategy for bringing together ground-based, aircraft and satellite observations was created under the IGACO (Integrated Global Atmospheric Chemistry Observations) program and is presented in the IGACO-Ozone and UV Radiation Implementation Plan (Braathen et al., 2008). New environmental services are emerging within the European Union flagship programme Copernicus (http://www.copernicus.eu) on monitoring the Earth's environment using satellite and in situ observations. Such emerging services requiring atmospheric composition data include the Copernicus Climate Change Service (http://climate.copernicus.eu/) and the Copernicus Atmosphere Monitoring Service (http://atmosphere.copernicus. eu).

The Global Ozone Monitoring Experiment-2 (GOME2) instrument is targeted to fulfill these expectations. It is one of the new-generation of European nadir looking instruments carried on the Metop platforms which are part of the EUMETSAT Polar System (EPS). The GOME-2 instruments will continue the long-term monitoring of atmospheric constituents started by the BUV instrument onboard the Nimbus-4 satellite in 1970 (Heath et al., 1973). The nadir measurements were continued by the SBUV and TOMS instruments (Heath et al., 1975) onboard NOAA satellites and ESA's GOME instrument on ERS-2 (Callies et al., 2000; Munro et al., 2006). Other instruments that have been used to study atmospheric composition are for example the SCIAMACHY (Bovensmann et al., 1999), MIPAS (Fischer and Oelhaf, 1996) and GOMOS (Bertaux et al., 1991) instruments onboard ESA's Envisat platform as well as SAGE and SAGE II on NASA's platforms. Currently operational instruments measuring atmospheric composition include the Dutch-Finnish OMI on board NASA's Aura satellite, NASA's OMPS instrument on the Suomi-NPP satellite and the Canadian OSIRIS onboard the Swedish Odin satellite (Llewellyn et al., 2003). The long-term monitoring will be continued by the next generation instruments, the Dutch Tropomi onboard ESA's Sentinel 5-Precursor satellite (launch in 2016), followed by the Copernicus Sentinel5/UVNS instruments onboard EPS-SG covering the time period 2020-2035. Furthermore, atmospheric composition, es- pecially for air-quality purposes, will be monitored with the Sentinel-4 instruments onboard the geostationary MTG (Meteosat Third Generation) platforms.

As an operational mission, continuity of GOME-2 observations is ensured by three identical instruments onboard three Metop platforms: A, B and C: The first was launched in 2006, the second in 2012 and the last one will be launched in 2018. The GOME-2 instruments will provide unique longterm data sets of 15 years related to atmospheric composition and surface ultra violet (UV) radiation using stable retrieval techniques. The GOME-2 is set to make a significant contribution towards climate and atmospheric research, whilst providing near-real-time data for use in air quality forecasting.

The GOME-2 instrument was designed and built at the time of the strongest ozone depletion and thus, one of its main objectives is to monitor ozone, ozone chemistry and the development of the ozone depletion. The ozone layer is on track to recovery, states the WMO Scientific Assessment of Ozone Depletion: 2014 (World Meteorological Organization, 2014). Thus, the scientific value of the GOME-2 instrument measurements will also continue in the future.

The provision of an operational 24/7 service is also an important response to the expectations outlined above. The Level 2 GOME-2 product development, processing, dissemination and user services are the responsibility of the Satellite Application Facility on Ozone and Atmospheric Chemistry Monitoring (O3M SAF) project, which is an integral part of the distributed EUMETSAT Application Ground Segment. The product development includes extensive product reviews focusing on product requirements, product algorithms as well as validation results. Furthermore, the ground segment processing chains have been reviewed, keeping in mind the 24/7 requirement for processing and dissemination. The production includes continuous quality control for the processing and products.

The current L2 data cover a wide range of products, such as ozone (total and tropospheric columns) and trace gas columns (total and tropospheric $\mathrm{NO}_{2}$, total $\mathrm{BrO}, \mathrm{HCHO}$, $\mathrm{H}_{2} \mathrm{O}, \mathrm{SO}_{2}$ ), vertical ozone profiles in high and low spatial resolution, absorbing aerosol indices from the main as well as from the polarisation channels (AAI, AAI-PMD), surface Lambertian-equivalent reflectivity (LER) database, clear-sky and cloud-corrected UV indices and surface UV fields with different weightings and $\mathrm{NO}_{2}$ and $\mathrm{O}_{3}$ photolysis rates. In future, the products will include glyoxal and $\mathrm{BrO}$ as well as special climate data sets of $\mathrm{H}_{2} \mathrm{O}$ and $\mathrm{NO}_{2}$ and absorbing aerosol height.

The O3M SAF started in 2004 with a development phase, and the first operational Continuous Development and Operations Phase started in 2007. The second phase started in 2012 and the third one will start in 2017. Besides GOME-2 products, the O3M SAF, together with the EUMETSAT, will also provide some new IASI products. The first IASI product, carbon monoxide, will be released in early 2016. The project 
description as well as product information, documentation, a helpdesk, user services and the dissemination services are available from the project web site (http://o3msaf.fmi.fi).

The purpose of this paper is to give an overall description of the GOME-2 activities and products provided by the O3M SAF project. The paper is organised as follows: The instrument and ground segment are described in Sects. 2 to 4 , retrieved parameters with key validation summaries are presented in Sect. 5 and the emerging products in Sect. 6.

\section{The GOME-2 instrument}

The GOME-2 instruments onboard the Metop satellite platforms are direct successors to the GOME instrument that was flying onboard the ERS-2 platforms and thus, the basic concept is the same. However, quite a number of changes to the GOME instrument design have been imposed by the fact that Metop is a very different satellite from ERS-2, designed for a different orbit. For example, the new orbit imposes a different viewing angle towards the Sun, for in-orbit calibration purposes, and some moderate changes in the instrument's thermal environment (Callies et al., 2000).

The GOME-2 instrument is a nadir looking and scanning UV-VIS spectrometer that measures backscattered solar light. GOME-2 is comprised of four main optical channels of 1024 pixels giving in total 4096 spectral channels for a range of 240-790 nm and a spectral resolution of 0.26$0.51 \mathrm{~nm}$. Furthermore, the two polarisation measurement devices (PMDs) containing the same type of arrays for measurement of linearly polarised intensity in two perpendicular directions provide 30 broad-band polarisation channels. A detailed description of the instrument is given in Munro et al. (2015).

The Metop satellites are flying in sun-synchronous orbits with equator crossing times of approximately 09:30 LT (descending node) and a repeat cycle of 29 days. The default swath width of the GOME-2 scan is $1920 \mathrm{~km}$, which gives a nadir pixel size of $80 \times 40 \mathrm{~km}$ (across-track $\times$ long-track) and enables global coverage in about 1.5 days. The current primary GOME-2B is operated in this mode, whereas the older GOME-2A is operated in a reduced swath with a swath width of $960 \mathrm{~km}$ and nadir ground pixel size of $40 \times 40 \mathrm{~km}$. The GOME-2A is expected to be operational until the launch of the Metop-C platform in 2018.

\section{$3 \quad$ LO and L1 processing}

The EUMETSAT central processing facility, located in Darmstadt, is responsible for the processing of all GOME2 data up to Level $1 \mathrm{~b}$ (current version 6.1.0). This processing is carried out within the Core Ground Segment (CGS) by the GOME-2 Product Processing Facility (PPF) which converts raw instrument data (Level 0 data stream) into timestamped, geolocated, and fully spectrally and radiometrically calibrated radiances or irradiances (Level $1 \mathrm{~b}$ data stream). The Level $1 \mathrm{~b}$ data are delivered to the $\mathrm{L} 2$ processing centres in near-real-time via EUMETCast. The details of GOME-2 instrument design, calibration and $\mathrm{L} 1$ processing is described in Munro et al. (2015).

Instruments measuring in the UV and the short-wave visible regions are known to be sensitive to effects of contamination and to degradation of their optical elements. The magnitude and impact of degradation on the instrument signal level and therefore the quality of the calibrated Level-1 radiance products varies significantly with both wavelength and instrument design. The impact on overall signal throughput and therefore on signal-to-noise levels, through contamination or degradation of optical elements, generally increases towards shorter wavelengths. In addition, the impact on the product quality is very much determined by the changes in reflectance, relevant for many Level-2 retrievals, i.e. the difference in the way the quality of the solar radiance measurements is affected in contrast to the change in quality of the Earth radiance measurements. This difference in degradation between the two optical light paths is often referred to as differential degradation and is very much dependent on instrument design, i.e. on the number and type of optical elements used which are different for the two light paths (e.g. solar diffusers and other optical elements in the instrument calibration units (Munro et al., 2015). Differential degradation may also vary strongly with wavelength but, in contrast to absolute signal level degradation, may exhibit significant spectral variation of different signs and magnitudes over the full spectrum. This type of degradation may also vary depending on viewing geometry. The latter is especially true for instruments using scanning mirrors, such as GOME-1, GOME-2 and SCIAMACHY. Spectrally varying, and viewing geometry dependent differential degradation may also have an impact on the Level-2 retrievals, which are otherwise insensitive to absolute signal-level broad-band biases and degradation, like DOAS-type retrievals.

The GOME-2 instrument shows quite similar degradation overall compared to the GOME-1 instrument (ColdeweyEgbers et al., 2008), especially for the shortest wavelengths between 240 and $300 \mathrm{~nm}$, since the overall design, including the design of the solar path and the on-board calibration unit, is very similar for the two instruments. However, higher absolute degradation levels are observed for GOME2 in the region between 300 and $450 \mathrm{~nm}$. This is true for both GOME-2 instruments on Metop-A and B, which degrade very similarly in the absolute signal level. While the degradation for the shortest wavelengths is very likely to be due to the degradation of the throughput or the reflectivity of optical surfaces, e.g. the scanning mirror, the most likely candidate for the additional degradation observed in the region between 300 and $450 \mathrm{~nm}$ is contamination of optical surfaces across the whole optical path by the outgassing of conformal coatings of detector read-out electronics. These electronic boards have been moved closer to the detector housing for the 
GOME-2 design in order to increase read-out efficiency with respect to GOME-1. The overall spectral signature of differential degradation is in turn more similar to that observed for GOME-1, with the largest spectral signature evolving in the region around 450 to $500 \mathrm{~nm}$. For GOME-1 this spectral signature is assumed to originate from a contamination layer building up over time on the scanning mirror and is strongly scan angle dependent. It evolved at shorter wavelengths than for GOME-2 but with a similar temporal evolution and magnitude. For more details on GOME-2 radiance and reflectance degradation we refer to (EUMETSAT, 2012).

The impact of GOME-2 instrument degradation on Level2 product quality is therefore very much dependent on the spectral region and the type of retrieval methods chosen. The impact can range from no impact, an impact on the fit-quality but no impact on the retrieved concentrations, to an impact on the retrieved column or profile concentrations and their spatial scatter or long-term variations. For further details we refer to two studies on the impact of GOME-2 on Metop-A and GOME- 2 on Metop-B instrument degradation on Level2 retrieval quality carried out by Dikty et al. (2011) and Azam et al. (2015).

\section{$4 \quad$ L2 processing and archiving services}

The O3M SAF GOME-2 Level 2 products are developed and processed in a distributed EUMETSAT ground segment with four processing centres and two archives. The leading entity, the Finnish Meteorological Institute (FMI), processes and archives the offline UV products as well as archives the offline absorbing aerosol index and vertical ozone profile products and LER data set processed at Royal Netherlands Meteorological Institute (KNMI). The Deutsches Zentrum für Luft- und Raumfahrt (DLR) processes, archives and disseminates total and tropospheric trace gas column products. The NRT (near-real-time) products are disseminated via EUMETCast and the WMO Global Telecommunication System network directly by the processing centres except the NRT UV products which are processed by the Danish Meteorological Institute (DMI) and distributed via http and FTP. The internal O3M SAF product, assimilated GOME-2 total ozone analysis and forecast (Eskes et al., 2003), is based on O3M SAF GOME-2 total ozone and processed by KNMI and used by DMI in NRT UV production. Furthermore, the internal cloud products needed for trace gas column retrievals are processed by DLR.

The O3M SAF GOME-2 products undergo an extensive review process during the development before they can be declared operational. The validation activities are an important part of this review process. The validation is mainly performed by the specialised validation entities: Aristotle University of Thessaloniki, Belgian Institute for Space Aeronomy, German Weather Service, Royal Meteorological Institute and Mariolopoulos - Kanaginis Foundation. On top of that, online quality monitoring services have been implemented by the processing and validation institutes so that the product users may check the latest information regarding product quality. Online quality monitoring uses external satellite and ground-based data and plotting of trends and special parameters. The data delay ranges from a few minutes up to a few days depending on what kind of method is used.

The main distribution channel for the NRT data is EUMETCast, utilising the Eurobird-9 satellite. EUMETCast is a multi-service dissemination system based on standard Digital Video Broadcast technology that uses commercial telecommunication geostationary satellites to multi-cast files (data and products) to a wide user community. The channel SAF-Europe transmits nearly all products in HDF5 format and channel SAF-Africa transmits trace gases as HDF5 and ozone profile products in BUFR (binary universal form for the representation of universal data) format. Furthermore, trace gas column and ozone profile products are available in BUFR format via the WMO Global Telecommunication System. The trace gas products may also be obtained by using the FTP services and in the case of NRT UV via a dedicated web page, FTP and Google Earth. The timeliness requirement for the NRT products is $3 \mathrm{~h}$ from sensing.

The offline products as well as long-term data records are available in HDF5 format from the data archives hosted by FMI and DLR. Both of these archives are accessible via a registration and data ordering service that is available on the O3M SAF main web site (http://o3msaf.fmi. fi/). Furthermore, the offline data are also available using the EUMETSAT Earth Observation Portal (https://eoportal. eumetsat.int/). The timeliness requirement for the offline products is 2 weeks from sensing. The data are free of charge. However, the registration is a mandatory step when retrieving data for the first time.

The daily updated example images of the O3M SAF products are available from the O3M SAF web site. Furthermore, images of several O3M SAF GOME-2 products are also available on the TEMIS scientific data portal (www. temis.nl), where GOME-2 data can be compared and combined with data from GOME, SCIAMACHY and OMI. The O3M SAF L2 data can be used with The Basic Envisat Atmospheric Toolbox (BEAT) and VISAN (BEAT visualisation package). The interfaces and description files are implemented into the BEAT by the S\&T company.

Beside broadcast dissemination and FTP/http downloads, the O3M SAF provides web mapping services for trace gas data in three distinct timeliness categories: latest NRT data of today updated every $15 \mathrm{~min}$, NRT data of yesterday and mission-lifetime time series of daily offline data. These services have been established and operated by DLR (Heinen et al., 2009) and they comply to the OGC (Open Geospatial Consortium) standards Web Map Service for visualisation and Web Coverage Service for download. 
The O3M SAF GOME-2 offline archives have 236 registered users in 41 countries (September 2015). They downloaded about $1.4 \mathrm{~Tb}$ of Level 2 data in June 2015 alone. At the same time, the amount of archived data was about $10 \mathrm{~Tb}$ with a monthly increase of about $260-300 \mathrm{~Gb}$. Furthermore, the project has 731 (September 2015) users together in 78 countries who have registered for the EUMETCast NRT service. The number of users that receive the data via the WMO Global Telecommunication System is unknown. Overall, the usage of the O3M SAF GOME-2 data is extensive, and there are users in every continent.

All retrieval options with instructions together with the product documentation, such as Algorithm Theoretical Basis Documents, validation reports and product user manuals as well as ordering interfaces and links to validation and online quality monitoring sites are available from the project web site: http://o3msaf.fmi.fi.

\section{Operational O3M SAF GOME-2 products}

The currently operational and available products are shown in Tables 1 and 2. The following sub-chapters provide an overview of those products with validation examples. Most of the products are available both from the GOME-2A and GOME-2B instruments. By using both instruments together, global coverage may be obtained in 1 day. Merged L3 products will be available during the next phase, starting in 2017.

The original accuracy targets for Level 2 products were defined in the EUMETSAT Polar System End-User Requirements Document. The requirements specified in this document were established in coordination with user representatives. Each product is subject to a requirements review before the product can be implemented and declared operational. The objective is to recheck the accuracy requirements together with the availability and format requirements. Thus, the accuracy requirements for operational products mentioned in Table 1 reflect the evolving user needs as well as improved retrieval algorithms.

\subsection{Total ozone column}

Total ozone columns are retrieved from GOME-2 (ir)radiance spectra using the DOAS method (Platt and Stutz, 2008) in the wavelength region $325-335 \mathrm{~nm}$ (Huggins absorption band). The fitting includes an effective temperature for the ozone absorption, an $\mathrm{NO}_{2}$ absorption cross-section, and scaling factors for interference due to the Ring effect. The retrieved ozone slant column densities are converted to vertical columns using an iterative air mass factor. Furthermore, a cloud correction is applied in the vertical column retrieval for (partially) cloudy scenes. Cloud parameters are retrieved from GOME-2 using the OCRA and ROCINN algorithms (Loyola et al., 2007; Lutz et al., 2015). OCRA provides the cloud fraction using the PMD

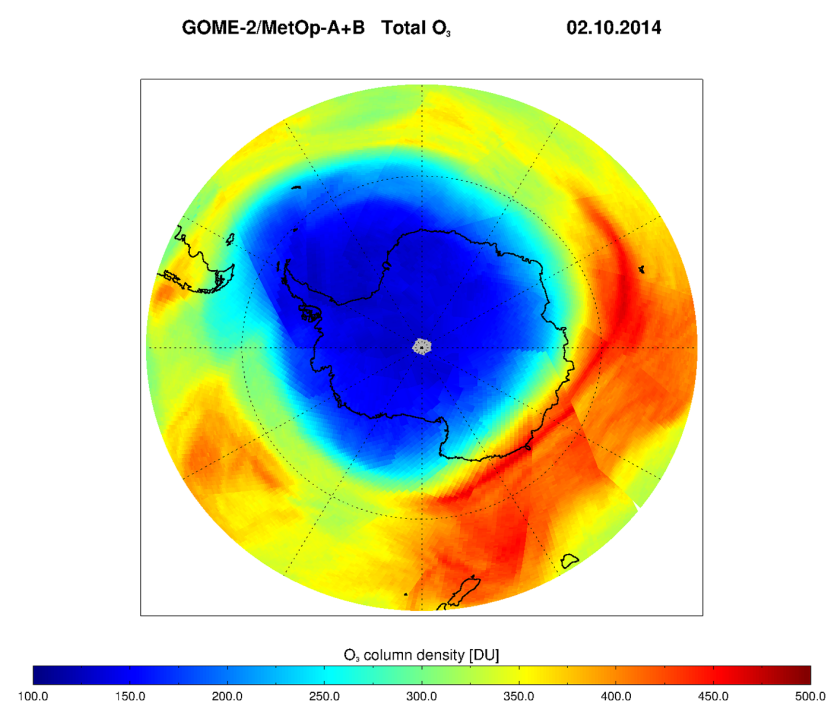

Figure 1. Total ozone map for 2 October 2014 based on data from GOME-2A and GOME-2B instruments.

measurements and ROCINN provides cloud height and cloud albedo using the oxygen A-band measurements. The cloud parameters retrieved from OCRA and ROCINN have been validated and verified by comparing with other measurements (Loyola et al., 2007) and other cloud algorithms (Richter, 2015). To reduce the impact of the instrument degradation, the degradation correction factors have been implemented in both the OCRA and ROCINN algorithms (Lutz et al., 2015). Note that the OCRA and ROCINN cloud parameters are also used for the cloud correction of the other minor trace gas column products $\left(\mathrm{NO}_{2}, \mathrm{BrO}, \mathrm{HCHO}, \mathrm{SO}_{2}\right.$ and water vapour) as well as for the determination of the tropical tropospheric ozone column product.

A detailed description of the GOME-2 total ozone column algorithm can be found in Van Roozendael et al. (2006), Loyola et al. (2011) and Hao et al. (2014). Figure 1 shows one example of the total ozone product: The Antarctic ozone hole for 2 October 2014 measured from GOME-2A and GOME$2 \mathrm{~B}$ when the minimum total ozone column reached was around $120 \mathrm{DU}$

The total ozone NRT and offline products from GOME-2A and GOME-2B are periodically validated and routinely monitored for their quality. For this purpose, a dedicated webportal is available at http://lap3.physics.auth.gr/eumetsat. In this portal, online comparisons with quality assured groundbased total ozone measurements are available. The reference data for the offline total ozone comparisons are archived Brewer, Dobson and M-124 total ozone data; these are deposited at the World Ozone and UV Data Centre (http://www. woudc.org) and are employed after being thoroughly controlled for their quality. These online comparisons are routinely and automatically updated every month. For the nearreal-time total ozone comparisons, near-real time Brewer and 
Table 1. O3M SAF GOME-2 L2 products available to users, a summary table showing physical properties. HR $\mathrm{O}_{3}$ profile refers to high spatial resolution ${ }^{\mathrm{a}}$ ozone profile product whereas $\mathrm{LR}_{3}$ profile refers to low spatial resolution ${ }^{\mathrm{a}}$ ozone profile product.

\begin{tabular}{|c|c|c|c|c|c|}
\hline Product & Unit & Target accuracy & Spatial res. ${ }^{\mathrm{a}}$ & Type & Wavelengths \\
\hline Total ozone & DU & $4 \% / 6 \%^{b}$ & $80 \times 40 \mathrm{~km}$ & Column & $325.0-335.0 \mathrm{~nm}$ \\
\hline Tropical trop. ozone & DU & $25 \%$ & $1.25^{\circ} \times 2.5^{\circ}$ & Column & $325.0-335.0 \mathrm{~nm}$ \\
\hline Global trop. ozone & DU & $20 \%$ & $80 \times 40 \mathrm{~km}$ & & $265.0-330.0 \mathrm{~nm}$ \\
\hline $\mathrm{HR} \mathrm{O}_{3}$ profile & DU & $15 \% / 30 \%{ }^{\mathrm{c}}$ & $80 \times 40 \mathrm{~km}$ & Profile $^{\mathrm{d}}$ & $265.0-330.0 \mathrm{~nm}$ \\
\hline $\mathrm{LR} \mathrm{O}_{3}$ profile & DU & $15 \% / 30 \%{ }^{\mathrm{c}}$ & $640 \times 40 \mathrm{~km}^{\mathrm{e}}$ & Profile $^{\mathrm{d}}$ & $265.0-330.0 \mathrm{~nm}$ \\
\hline Total $\mathrm{NO}_{2}$ & molec $\mathrm{cm}^{-2}$ & $3-5 \times 10^{14 f}$ & $80 \times 40 \mathrm{~km}$ & Column & $425.0-450.0 \mathrm{~nm}$ \\
\hline Trop. $\mathrm{NO}_{2}$ & molec $\mathrm{cm}^{-2}$ & $30 \% \mathrm{f}$ & $80 \times 40 \mathrm{~km}$ & Column & $425.0-450.0 \mathrm{~nm}$ \\
\hline Total $\mathrm{SO}_{2}$ & DU & $50 \% \mathrm{~g}$ & $80 \times 40 \mathrm{~km}$ & Column & $315.0-326.0 \mathrm{~nm}$ \\
\hline Total BrO & molec $\mathrm{cm}^{-2}$ & $30 \%$ & $80 \times 40 \mathrm{~km}$ & Column & $332.0-359.0 \mathrm{~nm}$ \\
\hline Total HCHO & molec $\mathrm{cm}^{-2}$ & $50 \%$ & $80 \times 40 \mathrm{~km}$ & Column & $328.5-346.0 \mathrm{~nm}$ \\
\hline Total $\mathrm{H}_{2} \mathrm{O}$ & $\mathrm{kg} \mathrm{m}^{-2}$ & $10 \%$ & $80 \times 40 \mathrm{~km}$ & Column & $614.0-683.2 \mathrm{~nm}$ \\
\hline AAI & unitless & 0.5 & $80 \times 40 \mathrm{~km}$ & Index & $340,380 \mathrm{~nm}$ \\
\hline AAI from PMD & unitless & 0.5 & $10 \times 40 \mathrm{~km}$ & Index & $338,381 \mathrm{~nm}$ \\
\hline UV index & unitless & $20 \%$ & $0.5^{\circ} \times 0.5^{\circ}$ & Index & \\
\hline UV daily dose $\mathrm{e}^{\mathrm{h}}$ & $\mathrm{kJ} \mathrm{m}^{-2}$ & $20 \%$ & $0.5^{\circ} \times 0.5^{\circ}$ & Surface & \\
\hline UV max. dose $\mathrm{e}^{\mathrm{h}}$ & $\mathrm{mW} \mathrm{m}^{-2}$ & $20 \%$ & $0.5^{\circ} \times 0.5^{\circ}$ & Surface & \\
\hline $\mathrm{NO}_{2}$ photolysis & $1 / \mathrm{s}$ & $20 \%$ & $0.5^{\circ} \times 0.5^{\circ}$ & Surface & \\
\hline $\mathrm{O} 3$ photolysis & $1 / \mathrm{s}$ & $20 \%$ & $0.5^{\circ} \times 0.5^{\circ}$ & Surface & \\
\hline UVI clear & $\mathrm{W} \mathrm{m}^{-2}$ & $20 \%$ & $0.25^{\circ} \times 0.25^{\circ}$ & Index & \\
\hline UVI cloud-corrected & $\mathrm{W} \mathrm{m}^{-2}$ & $20 \%$ & $0.25^{\circ} \times 0.25^{\circ}$ & Index & \\
\hline LER $^{\mathrm{i}}(\mathrm{MSC}$ PMD) & unitless & 0.04 & $0.5^{\circ} \times 0.5^{\circ}$ & Index & $325-772 \mathrm{~nm}, 325-799 \mathrm{~nm}$ \\
\hline \multicolumn{6}{|l|}{ Emerging products } \\
\hline Tropospheric BrO & molec $\mathrm{cm}^{-2}$ & $30 \%$ & $80 \times 40 \mathrm{~km}$ & Column & \\
\hline Glyoxal & molec $\mathrm{cm}^{-2}$ & $50 \%$ & $80 \times 40 \mathrm{~km}$ & Column & \\
\hline $\mathrm{OClO}$ & molec $\mathrm{cm}^{-2}$ & $50 \%$ & $80 \times 40 \mathrm{~km}$ & Column & \\
\hline Monthly mean $\mathrm{H}_{2} \mathrm{O}$ & $\mathrm{kg} \mathrm{m}^{-2}$ & & & Column & \\
\hline Monthly mean $\mathrm{NO}_{2}$ & molec $\mathrm{cm}^{-2}$ & & & Column & \\
\hline \multicolumn{6}{|l|}{ Auxiliary products } \\
\hline Cloud fraction & unitless & & $80 \times 40 \mathrm{~km}$ & Fraction & $300-800 \mathrm{~nm}$ \\
\hline Cloud pressure & $\mathrm{hPa}$ & & $80 \times 40 \mathrm{~km}$ & Pressure & $758-771 \mathrm{~nm}$ \\
\hline Cloud albedo & unitless & & $80 \times 40 \mathrm{~km}$ & Albedo & $758-771 \mathrm{~nm}$ \\
\hline Assimilated total $\mathrm{O}_{3}$ & DU & & $80 \times 40 \mathrm{~km}$ & Column & \\
\hline \multicolumn{6}{|c|}{$\begin{array}{l}\text { Spatial resolution: nominal MSC (main science channels) pixel size for GOME- } 2 \text { is } 80 \times 40 \mathrm{~km} \text {. The GOME- } 2 \mathrm{~B} \text { instrument is operated with this } \\
\text { resolution, whereas GOME- } 2 \mathrm{~A} \text { has been providing resolution of } 40 \times 40 \mathrm{~km} \text { since July } 2012 \text {. For PMD (polarisation measurement device) the } \\
\text { corresponding resolutions are } 10 \times 40 \text { and } 5 \times 40 \mathrm{~km} \text {. Only the GOME- } 2 \mathrm{~B} \text { resolution is indicated in this column. }{ }^{\mathrm{b}} 4 \% \text { for SZA (solar zenith } \\
\text { angle) }<80^{\circ} \text { and } 6 \% \text { for SZA }>80^{\circ} \cdot{ }^{\mathrm{c}} 15 \% \text { for stratosphere and } 30 \% \text { for troposphere } \mathrm{d} \text { ozone profiles up to } 0.001 \mathrm{hPa}, 40 \text { layers. }{ }^{\mathrm{e}} 80 \times 40 \text { ground } \\
\text { pixel resolution follows the integration time of the } 1 \mathrm{~B} \text { channel, whereas } 640 \times 40 \text { integration time follows UV wavelengths. }{ }^{f} \text { Accuracy of total } \mathrm{NO}_{2} \text { in } \\
\text { unpolluted conditions and tropospheric } \mathrm{NO}_{2} \text { in polluted conditions. }{ }^{\mathrm{g}} \mathrm{SZA}<70^{\circ} \text {. }{ }^{\mathrm{h}} \text { Offline UV product has the following weighting functions: } \\
\text { erythemal (CIE), plant response, DNA damage, UVA, UVB, D-vitamin. }{ }^{\mathrm{i}} \text { Lambertian equivalent reflectivity. Resolution for MSC (main science } \\
\text { channels) product is } 1^{\circ} \times 1^{\circ} \text { and for PMD product } 0.5^{\circ} \times 0.5^{\circ} \text {. }\end{array}$} \\
\hline
\end{tabular}

Dobson total ozone data, deposited in the World Meteorological Organisation Ozone Mapping Center (http://lap.physics. auth.gr/ozonemaps2/), are downloaded and compared to the GOME-2A and GOME-2B near-real-time observations on a weekly basis.

Comparison results for the GOME-2A offline data for the period 2007-2011, processed with GDP4.4 (Loyola et al., 2011), have been previously presented by Koukouli et al. (2012), indicating that GOME-2 total ozone data agree at the $1 \%$ level with the ground-based measurements as well as other satellite instrument data sets, showing a small dependency on solar zenith angle for angles less than $75^{\circ}$ and almost no dependency on cloud fraction and cloud top pressure. Results from an initial validation of the GOME-2B offline data, processed with GDP4.7 for the year 2013, have been presented in Hao et al. (2014). These results show excellent consistency with coincident GOME-2A total ozone measurements. In Fig. 2 we present an updated time series of the differences between GOME-2A and GOME-2B vs. Dobson and Brewer total ozone data, averaged over the North- 
Table 2. O3M SAF GOME-2 L2 products available to users, a summary table showing additional information. $\mathrm{HR} \mathrm{O}_{3}$ profile refers to high spatial resolution ozone profile product, whereas $\mathrm{LR} \mathrm{O}_{3}$ profile refers to low spatial resolution ozone profile product.

\begin{tabular}{|c|c|c|c|c|}
\hline Product & Inst $^{\mathrm{a}}$ & Processor vers. & Dissemination $^{\mathrm{b}}$ & Main application areas \\
\hline Total ozone & $\mathrm{A}, \mathrm{B}$ & 4.7 & NRT, Ol & Ozone chemistry, NWP \\
\hline Tropical trop. ozone & $\mathrm{A}, \mathrm{B}$ & 4.8 & $\mathrm{Ol}$ & Air quality \\
\hline Global trop. ozone & $\mathrm{A}, \mathrm{B}$ & 1.12 & NRT, Ol & Air quality \\
\hline $\mathrm{HR} \mathrm{O}_{3}$ profile & A, B & 1.12 & NRT, O1 & Ozone chemistry, protocol monitoring \\
\hline $\mathrm{LR} \mathrm{O}_{3}$ profile & $\mathrm{A}, \mathrm{B}$ & 1.12 & NRT, Ol & Ozone chemistry, protocol monitoring \\
\hline Total $\mathrm{NO}_{2}$ & $\mathrm{~A}, \mathrm{~B}$ & 4.7 & NRT, Ol & Ozone chemistry, climate change \\
\hline Trop. $\mathrm{NO}_{2}$ & $\mathrm{~A}, \mathrm{~B}$ & 4.7 & NRT, Ol & Air quality \\
\hline Total $\mathrm{SO}_{2}$ & $\mathrm{~A}, \mathrm{~B}$ & 4.7 & NRT, O1 & Aviation safety, emission monitoring \\
\hline Total BrO & $\mathrm{A}, \mathrm{B}$ & 4.7 & NRT, Ol & Ozone chemistry \\
\hline Total HCHO & $\mathrm{A}, \mathrm{B}$ & 4.7 & NRT, Ol & Air quality, climate change \\
\hline Total $\mathrm{H}_{2} \mathrm{O}$ & $\mathrm{A}, \mathrm{B}$ & 4.7 & NRT, Ol & Climate change \\
\hline AAI & $\mathrm{A}, \mathrm{B}$ & 1.28 & NRT, Ol & Aviation safety, RTM \\
\hline AAI from PMD & $\mathrm{A}, \mathrm{B}$ & 1.28 & NRT, Ol & Aviation safety, RTM \\
\hline UV index & $\mathrm{B}$ & 1.20 & $\mathrm{Ol}$ & Health research, monitoring \\
\hline UV daily dose $\mathrm{e}^{\mathrm{c}}$ & $\mathrm{B}$ & 1.20 & $\mathrm{Ol}$ & Health research, monitoring \\
\hline UV max. dose $e^{c}$ & $\mathrm{~B}$ & 1.20 & $\mathrm{Ol}$ & Health research, monitoring \\
\hline $\mathrm{NO}_{2}$ photolysis & $\mathrm{B}$ & 1.20 & $\mathrm{Ol}$ & Health research, air quality \\
\hline O3 photolysis & $\mathrm{B}$ & 1.20 & $\mathrm{Ol}$ & Health research, air quality \\
\hline UVI clear & $\mathrm{B}$ & 3.3 & NRT & Health warnings \\
\hline UVI cloud-corrected & $\mathrm{B}$ & 3.3 & NRT & Health warnings \\
\hline LER (MSC, PMD) & A & 1.0 & DR & RTM \\
\hline \multicolumn{5}{|l|}{ Emerging products } \\
\hline Tropospheric BrO & A, B & & $\mathrm{Ol}$ & Health research, air quality \\
\hline Glyoxal & A, B & & $\mathrm{Ol}$ & Health research, air quality \\
\hline $\mathrm{OClO}$ & A, B & & NRT, Ol & Health research, air quality \\
\hline Monthly mean $\mathrm{H}_{2} \mathrm{O}$ & A, B & & $\mathrm{Ol}$ & Climate studies \\
\hline Monthly mean $\mathrm{NO}_{2}$ & $\mathrm{~A}, \mathrm{~B}$ & & $\mathrm{Ol}$ & Climate studies \\
\hline \multicolumn{5}{|l|}{ Auxiliary products } \\
\hline Cloud fraction & $\mathrm{A}, \mathrm{B}$ & & NRT, Ol & Total column products \\
\hline Cloud pressure & $\mathrm{A}, \mathrm{B}$ & & NRT, Ol & Total column products \\
\hline Cloud albedo & A, B & & NRT, Ol & Total column products \\
\hline Cloud assimilated total $\mathrm{O}_{3}$ & A, B & & NRT & NRT UV \\
\hline
\end{tabular}

a Instrument: A refers to GOME-2A and B to GOME-2B. ${ }^{\mathrm{b}}$ NRT (near-real-time), Ol (offline), DR (data record). ${ }^{\mathrm{c}}$ Offline UV product has the following weighting functions: erythemal (CIE), plant response, DNA damage, UVA, UVB, D-vitamin.

ern Hemisphere for the period 2007-2014. This confirms the consistency between the two satellite data sets as well as their long-term stability. The use of BDM (Brion, Daumont and Malicet) absorption cross sections (Malicet et al., 1995) in the GDP4.7 version of the algorithm explains the overestimation of GOME-2 data, compared with the results presented earlier by Koukouli et al. (2012). Both satellites are consistent over the Northern Hemisphere with negligible latitudinal dependence, while over the Southern Hemisphere there is a systematic difference of $1 \%$ between the two satellite instruments.

A wide community is using the GOME-2 total ozone product provided by the O3M SAF. Since October 2013, total ozone column data have been assimilated in the Copernicus atmosphere core service project CAMS (Monitoring Atmospheric Composition and Climate) NRT system. The GOME-
2 ozone columns are also used in the Integrated Forecast System (IFS) of the European Centre for Medium-Range Weather Forecasts (ECMWF). Furthermore, the GOME-2 total ozone data were used in the WMO/UNEP Scientific Assessment of Ozone Depletion reports of 2010 and 2014. Other users are WMO World Ozone and Ultraviolet Radiation Data Centre, WMO Ozone Mapping Centre, DLR World Data Center for Remote Sensing of the Atmosphere as well as ESA Tropospheric Emission Monitoring Internet Service (TEMIS).

\subsection{Vertical ozone profiles}

The NRT and offline vertical ozone profile product (van Peet et al., 2009, 2014) uses reflectance measurements from 260 to $330 \mathrm{~nm}$ and iteratively finds the ozone profile best 

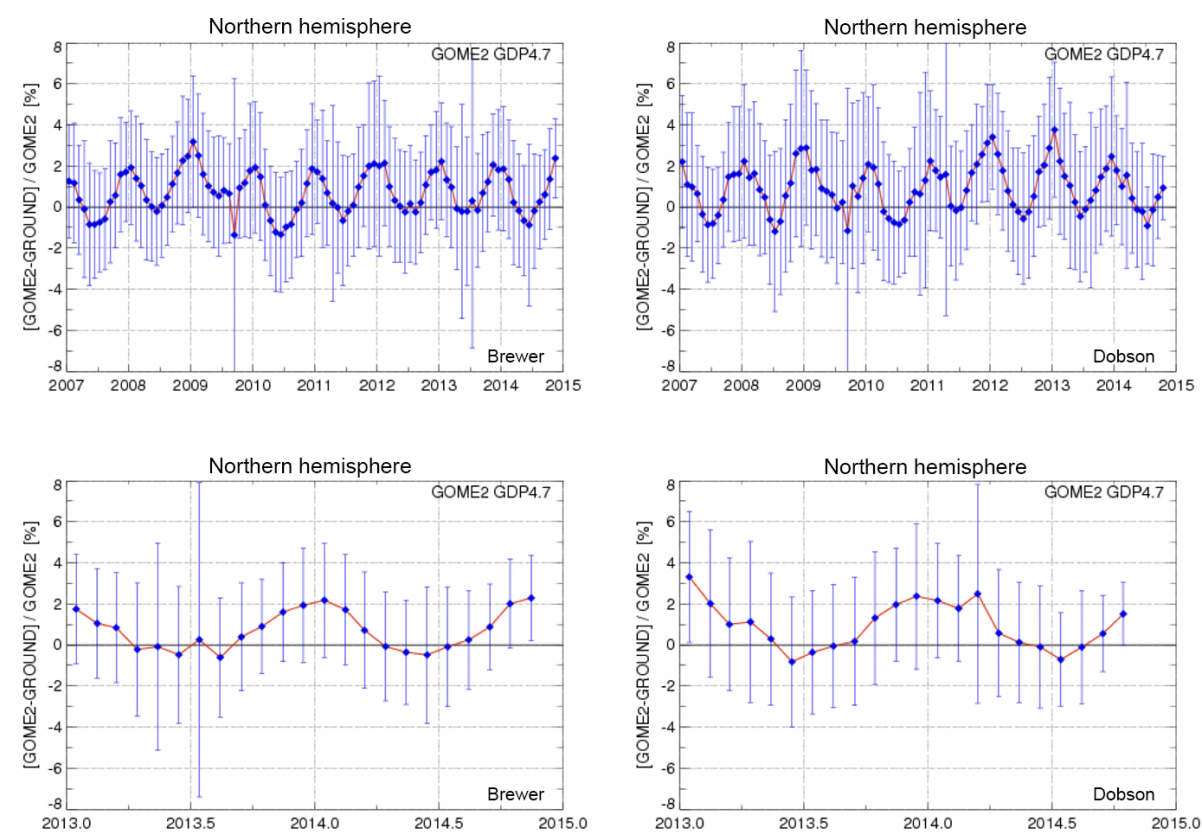

Figure 2. Monthly mean differences between GOME-2A (upper) and GOME-2B (lower) vs. ground-based total ozone columns; Brewer comparisons in the left column and Dobson comparisons in the right.

matching the original radiance measurements using optimal estimation. The ozone profiles are given as partial ozone columns in DU in 40 logarithmically spaced layers from the surface up to $0.001 \mathrm{hPa}$. For (partially) cloudy scenes, the retrieved cloud pressure replaces the nearest pressure level. The cloud pressure is retrieved by the FRESCO algorithm from the $\mathrm{O} 2$ A-band measurement of GOME-2 (Wang et al., 2008). GOME-2 has nominal spatial resolution of $80 \mathrm{~km} \times 40 \mathrm{~km}$, but for the shortest UV wavelengths the integration time is 8 times longer. The initial O3M SAF ozone profile product was provided at a spatial resolution of $640 \mathrm{~km} \times 40 \mathrm{~km}$ (coarse resolution, CR) but has since been improved to the $80 \mathrm{~km} \times 40 \mathrm{~km}$ resolution using radiance measurements from a mix of integration times. As an example of the ozone profile product from GOME-2B, Fig. 3 shows a vertical cross section along an orbit from north to south. The measurements end in a location over Antarctica where the Southern Hemisphere spring ozone hole is present, indicated by low ozone values in the stratosphere.

The ozone profile products are validated with ozone sonde data as well as with lidar and microwave measurements. The ozone sonde data are used in particular for the tropospheric and the lower stratospheric part up to about $30 \mathrm{~km}$, whereas lidar and microwave validation focus on the stratosphere from 15 to $55 \mathrm{~km}$. The ozone sonde data come from the World Ozone and Ultraviolet Radiation Data Center (WOUDC), the SHADOZ (Southern Hemisphere ADditional OZonesondes) network, NDACC (Network for the Detection of Atmospheric Composition Change) and the NILU's Atmospheric Database for Interactive Retrieval

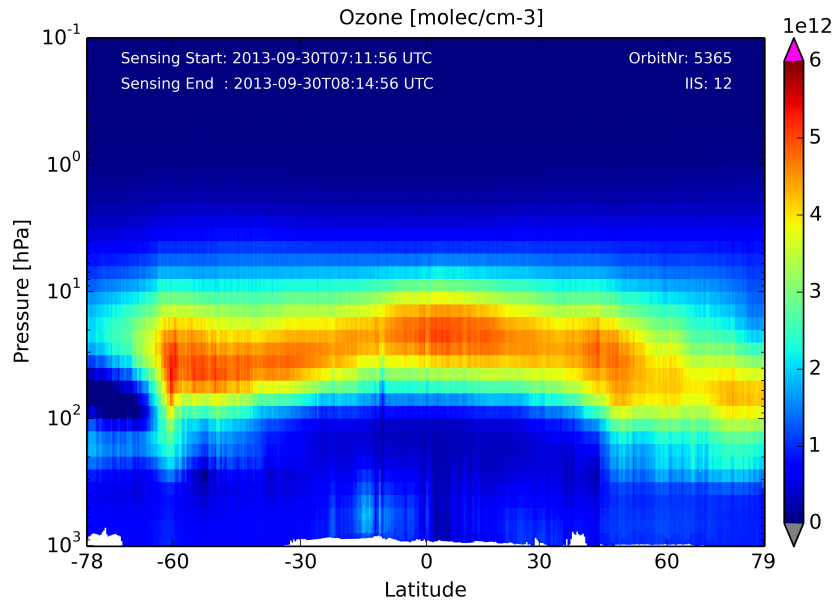

Figure 3. Vertical ozone profiles from GOME-2B, as a vertical cross section along an orbit from north to south. The measurements end in a location over the Antarctica where the Southern Hemisphere spring ozone hole is present, indicated by low ozone values in the stratosphere.

(NADIR) at Norsk Institutt for Luftforskning (NILU) (http: //www.nilu.no/nadir/). The NDACC network also provides the data of four lidar and five microwave stations. These are the only NDACC stations which deliver ozone profile data regularly and with a comparatively small delay. A comprehensive description of the ground-based validation methods and results for the upper stratosphere will soon be published elsewhere. 


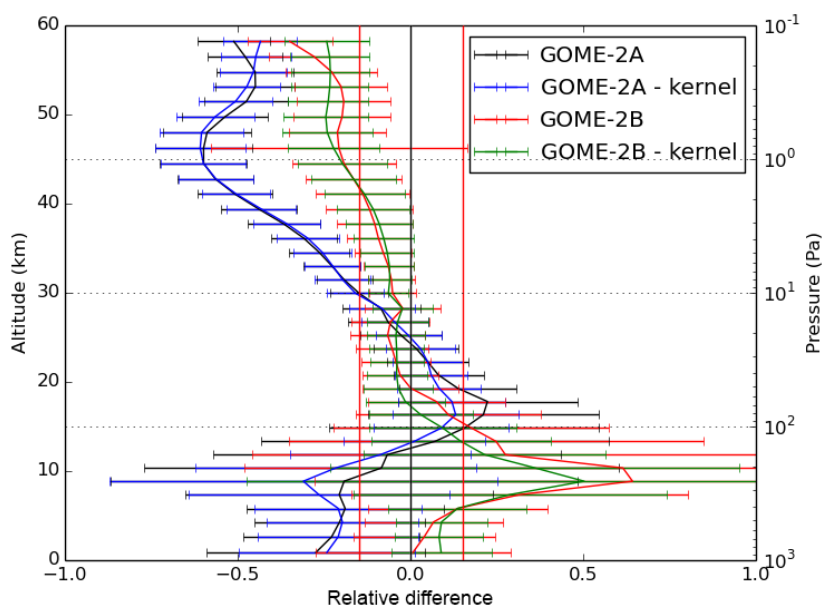

Figure 4. Relative differences between GOME-2A and GOME-2B ozone profiles (CR) and corresponding ozone sonde, lidar and microwave measurements. Shown is an average over all data from the years 2013 and 2014 for northern midlatitude stations. Up to $30 \mathrm{~km}$ altitude, all available ozone sondes are used for comparison, and above it is an average of two lidar (Hohenpeissenberg and Haute Provence) and two microwave stations (Bern and Payerne). The black (GOME-2A) and red (GOME-2B) curves are raw data, while the blue (GOME-2A) and green (GOME-2B) curves show data smoothed with the GOME-2 averaging kernel and a priori information. The red vertical lines mark the \pm sigma range of deviations.

The validation and quality monitoring is done by trending of monthly mean values and by direct comparison of satellite and ground-based data. The regular validation uses groundbased ozone profile measurements and considers the dependence of the deviations between satellite and ground-based profiles on total ozone, scan angle, solar zenith angle, cloud fraction and distance in space and time. All comparisons are performed for the high- and coarse-resolution satellite profiles, respectively. The complete set of results is regularly available at the O3M SAF validation internet site.

Overall target values are met in the troposphere $(30 \%)$ and the lower stratosphere $(15 \%)$, not taking into account the UTLS zone, which shows more elevated relative differences, which cannot be assigned to the troposphere or to the stratosphere. However, GOME-2 shows a clear underestimation of ozone concentrations above about $30 \mathrm{~km}$ (Fig. 4). The difference to ground-based data increases with altitude, amounting up to about $25 \%$ at $55 \mathrm{~km}$ for GOME-2B and up to about $55 \%$ for GOME-2A, depending to some degree on ground-based station and instrument. Furthermore, a satellite to satellite comparison with the Global Ozone Monitoring by Occultation of Stars (GOMOS), Optical Spectrograph and Infrared Imager System (OSIRIS) and Microwave Limb Sounder (MLS) confirms these conclusions (Kauppi et al., 2016).
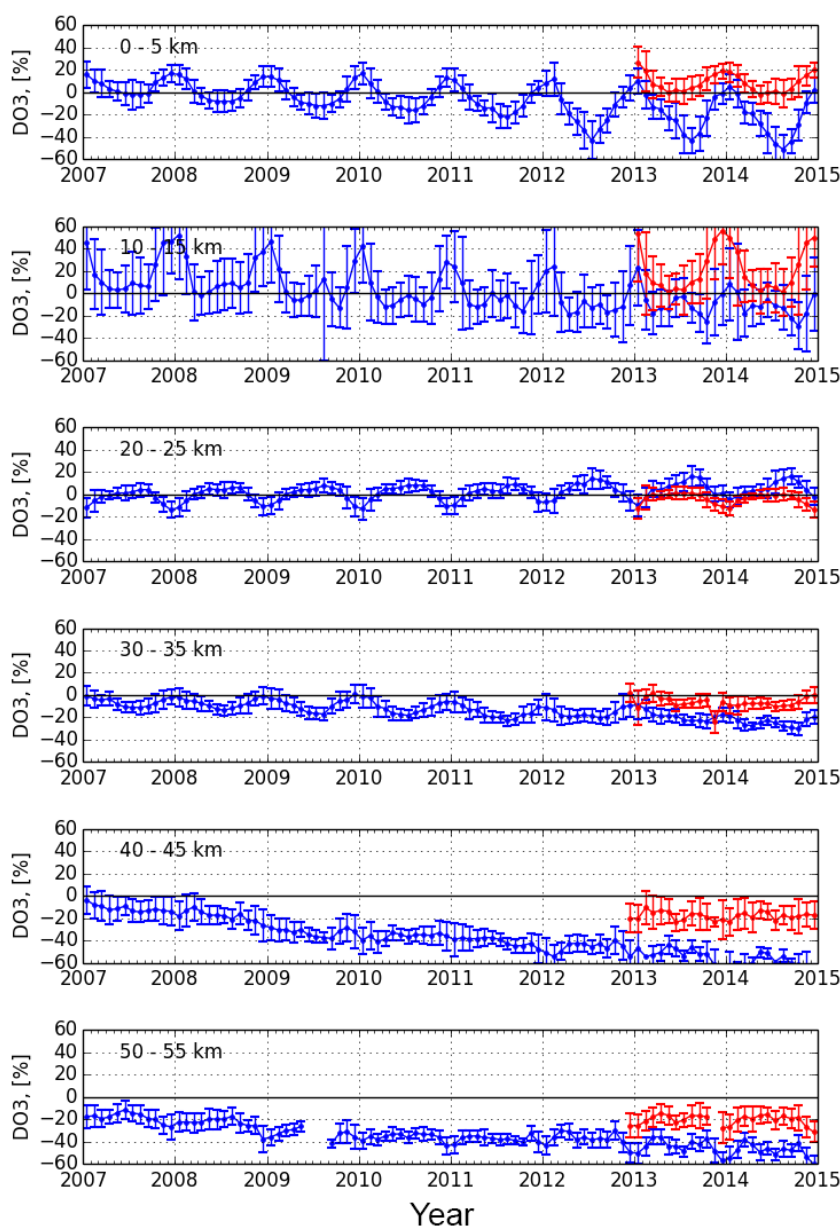

Figure 5. Time series of the relative differences between GOME2 ozone profiles (CR) and corresponding ground-based measurements. Shown are monthly mean values and their standard deviations. The data are averaged over all available stations at northern midlatitudes. At the three lower altitude layers, ozone sondes are used for comparison, and at the higher levels, two lidar (Hohenpeissenberg and Haute Provence) and two microwave stations (Bern and Payerne). The blue curves are for GOME-2A and the red ones for GOME-2B. All data are smoothed, by applying the GOME-2 averaging kernel and a priori information.

Degradation of the GOME-2A instrument is clearly visible in the ozone profile products as a decrease in retrieved ozone concentrations at most altitudes over the years of the mission (Fig. 5). Especially for the higher stratospheric part (above $30 \mathrm{~km}$ ), such a decrease could be identified. For the coarse-resolution profiles, this trend can be as large as $75 \%$ per decade in the upper stratosphere above $30 \mathrm{~km}$. GOME2B data (red lines in Fig. 5) do not yet show this effect.

Using a comparison between measured and expected/simulated spectra, a multiplicative bias factor can be established with which the measurement needs to be corrected. Figure 6 is an example of the bias factor for 267 and $329 \mathrm{~nm}$ for GOME-2A. Clearly visible is that there was 


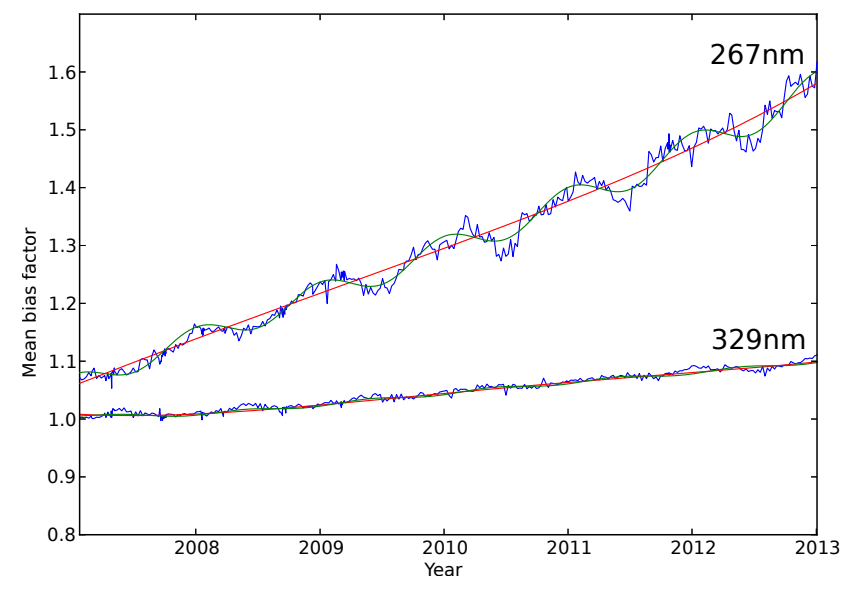

Figure 6. Degradation of the GOME-2A instrument, expressed as the ratio between the measured and simulated spectra (multiplicative bias factor) for 267 and $329 \mathrm{~nm}$. The blue lines indicate the weekly data points, the green lines are a fitted function (fourier + polynomial), and the red line is a long-term polynomial fit.

an initial bias at $267 \mathrm{~nm}$ of roughly $8 \%$, increasing to $60 \%$ in 2013 and that while the bias at $329 \mathrm{~nm}$ was initially minimal it has increased to about $10 \%$ in 2013 . The implementation of this degradation correction in the operational retrieval will be an important part of the algorithm development in the near future.

\subsection{Total and tropospheric $\mathrm{NO}_{2}$ column}

$\mathrm{NO}_{2}$ plays a key role in air quality and atmospheric chemistry. It is an air pollutant affecting human health and ecosystems, and an important ozone precursor. In addition, $\mathrm{NO}_{2}$ is involved in ozone depletion processes in the stratosphere and it is important for climate change studies, because of the indirect effect on the global climate. Total $\mathrm{NO}_{2}$ columns, including a tropospheric and stratospheric component, are retrieved with the DOAS method in the VIS wavelength region 425-450 nm (Valks et al., 2011). Tropospheric $\mathrm{NO}_{2}$ columns are obtained from the total columns by estimating the stratospheric content and removing it from the total amount. Several methods exist for the stratosphere estimation: Boersma et al. (2007), Richter and Burrows (2002) and Beirle et al. (2010). A spatial filtering approach (Wenig et al., 2004) is used by masking potentially polluted areas and then applying a low-pass filter in the zonal direction (Valks et al., 2011). After the stratosphere-troposphere separation, the tropospheric $\mathrm{NO}_{2}$ column is calculated using tropospheric air mass factors based on monthly average $\mathrm{NO}_{2}$ profiles from the MOZART2 chemistry transport model, and a cloud correction for partially cloudy conditions is applied (see also Sect. 5.1). Figure 7 shows the average tropospheric $\mathrm{NO}_{2}$ columns over East Asia measured by GOME-2A for the period 2007-2013. The world's largest area with high $\mathrm{NO}_{2}$ pollution is found

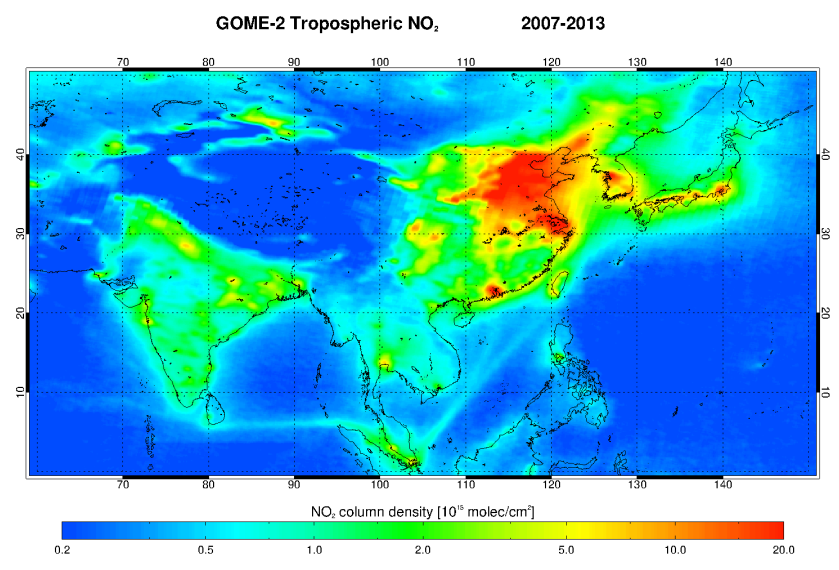

Figure 7. Average tropospheric $\mathrm{NO}_{2}$ columns over East Asia measured by GOME-2 for 2007-2013 (Logarithmic colour scale).

above eastern China, which is a result of China's spectacular economic growth during the last decade, accompanied by a strong increase in emissions of air pollutants. Another remarkable feature visible in Fig. 7 is the enhanced tropospheric $\mathrm{NO}_{2}$ along shipping lanes in the Bay of Bengal and the South China Sea, see also Richter et al. (2011).

The near-real-time and offline total and tropospheric $\mathrm{NO}_{2}$ products are regularly validated and monitored by comparing to (1) data sets acquired by other satellites (GOME, SCIAMACHY, OMI) and GOME-2 retrievals performed with other processors (such as the TEMIS system, http://www. temis.nl) and (2) ground-based reference measurements acquired by UV-visible DOAS zenith sky looking spectrometers performing network operation in the framework of the Network for the Detection of Atmospheric Composition Change (NDACC, http://ndacc.org) and zenith-sky looking spectrometers for the $\mathrm{NO}_{2}$ stratospheric column and multiaxis (MAX-DOAS) spectrometers for the $\mathrm{NO}_{2}$ tropospheric column. Detailed validation results for GOME-2A can be found in Valks et al. (2011). The results for the validation of GOME-2A and $\mathrm{B} \mathrm{NO}_{2}$ columns can be found in Pinardi et al. (2013) and on the O3M SAF BIRA validation pages (http://cdop.aeronomie.be/validation/valid-results).

The step by-step verification of the operational GOME$2 \mathrm{~B}$ product against GOME-2A, and GOME-2A and $\mathrm{B}$ alternative retrievals performed in Pinardi et al. (2014), has highlighted a global underestimation by GOME- $2 \mathrm{~B}$ slant columns of $1 \times 10^{15}$ molec cm ${ }^{-2}$ with respect to GOME-2A, which translates into a bias of $0.15 \times 10^{15}$ and $0.4 \times 10^{15}$ molec cm $^{-2}$ in total and stratospheric columns. GOME-2B tropospheric column data underestimate GOME-2A by less than $0.5 \times 10^{15}$ molec $\mathrm{cm}^{-2}$ in moderately polluted conditions, while larger differences (up to $8 \times 10^{15}$ molec $\mathrm{cm}^{-2}$ ) occur in polluted regions. The latter can be explained by the local time difference between GOME-2A and GOME-2B overpasses and the associated impact of the variability in $\mathrm{NO}_{2}$ content and cloud cover on 


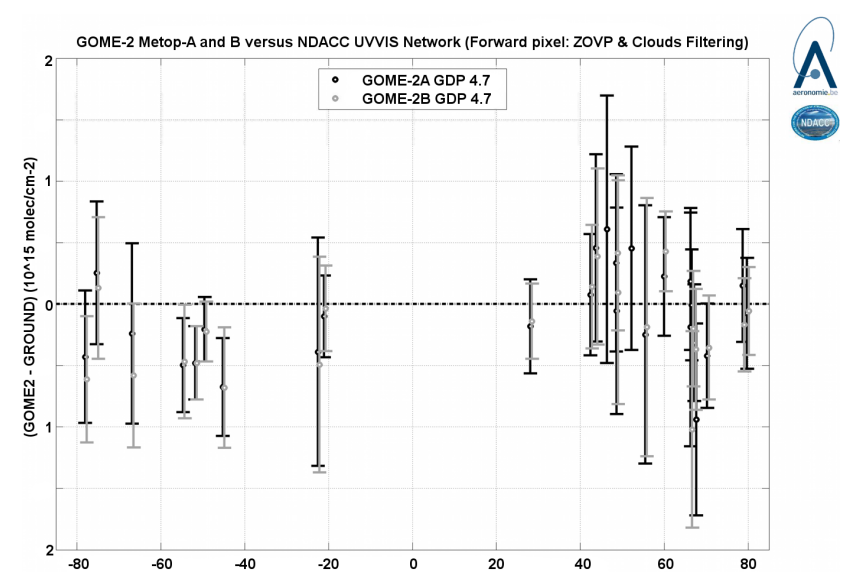

Figure 8. Example of total (stratospheric) $\mathrm{NO}_{2}$ validation: Poleto-pole structure of the median absolute difference between $\mathrm{NO}_{2}$ column data retrieved from GOME-2A/B (GDP 4.7) and from 25 ground-based zenith-sky DOAS spectrometers archiving consolidated data to NDACC DHF, calculated over 2007-2014 for GOME2A and 2013-2014 for GOME-2B.

the comparison results. Figure 8 presents, from pole to pole, the median bias and spread for total $\mathrm{NO}_{2}$ between GOME$2 \mathrm{~A} / \mathrm{B}$ total $\mathrm{NO}_{2}$ and correlative ground-based measurements acquired by 25 zenith-sky DOAS instruments. Prior to the comparisons, GOME-2/NDACC co-located data are filtered to avoid GOME-2 data contaminated by tropospheric pollution, and corrected for photochemical diurnal effects (arising from solar local time differences between NDACC and GOME-2 observations). Only the latest, consolidated versions of the NDACC data are considered for Fig. 8 (no NRT data), and only the GOME-2 forward pixels (no backward pixels) are considered. Figure 8 illustrates the good agreement between the different stratospheric $\mathrm{NO}_{2}$ data sets, usually within $0.1-0.5 \times 10^{14}$ molec $\mathrm{cm}^{-2}$, a value close to the combined uncertainty of the comparison method and within the target accuracies for total $\mathrm{NO}_{2}$ of $3-5 \times 10^{14}$ molec $\mathrm{cm}^{-2}$ in unpolluted conditions (Table 1). Nevertheless, the slight bias between GOME-2A and GOME-2B data is also seen in this figure with GOME-2B, underestimating GOME-2A by about $1-3 \times 10^{14}$ molec $\mathrm{cm}^{-2}$ (bias propagated from the retrieval of slant column densities), as well as another slight bias of $2-5 \times 10^{14} \mathrm{molec}^{-2}$ between comparison results averaged over the Northern Hemisphere and those averaged over the Southern Hemisphere.

Figure 9 presents some examples of validation results for tropospheric $\mathrm{NO}_{2}$ GOME-2 columns based on BIRA-IASB MAXDOAS stations. As can be seen in Fig. 9a, very different conditions of tropospheric $\mathrm{NO}_{2}$ are sampled at the four stations, from clean/remote region (OHP, south of France), city (Uccle, Belgium) and heavily polluted region in Beijing and Xianghe in China (just outside the city, at $60 \mathrm{~km}$ south-east of Beijing). Figure $9 \mathrm{~b}$ presents the scatter plots of the monthly means at the four stations. Good correla- tions between GOME-2A and the ground-based MAXDOAS data are obtained, both in terms of correlation coefficients $R$ (ranging from 0.65 in Uccle to 0.92 in Beijing) and slopes of the regression analysis $S$, with values $\sim 0.8$ at Xianghe, slightly smaller in Uccle and OHP $(\sim 0.6)$ and with larger differences $(S=0.47)$ in Beijing. The impact of the location of the ground-based instrument can be seen when comparing the results between Beijing and Xianghe, that are only $60 \mathrm{~km}$ apart: in the first case the MAXDOAS is situated in the centre of the Beijing megacity and then it has been moved to the Xianghe site outside the city, in a zone more representative of what is seen by a satellite pixel. This large differences in Beijing compared to results in Xianghe are due to a representation error for stations in urban locations, affected by local pollution episodes, not seen in the averaged GOME-2 pixel. This representation error has been also highlighted in larger scale comparisons started in Pinardi et al. (2014) for total, stratospheric and tropospheric GOME-2 $\mathrm{NO}_{2}$ columns compared to DirectSun, ZenithSky and MAXDOAS data sets. Figure 9c presents an example of the time series of GOME$2 \mathrm{~A}$ and $\mathrm{B}$ above $\mathrm{OHP}$ and its comparisons to ground-based MAXDOAS tropospheric $\mathrm{NO}_{2}$ data, extending the results presented in Valks et al. (2011). The pollution episodes are captured well by both GOME-2 instruments and the comparisons of monthly averaged columns show consistent seasonal variations, with high $\mathrm{NO}_{2}$ in winter and low $\mathrm{NO}_{2}$ in summer.

The GOME-2 tropospheric $\mathrm{NO}_{2}$ columns are used in the CAMS NRT system and in support of regional (e.g. European) air quality models, for example. The $\mathrm{NO}_{2}$ products from the O3M-SAF are also used by a number of research institutes for various applications such as verification of emissions, investigation of regional and global trends, and assessment of chemistry-transport models.

\subsection{Total HCHO column}

Atmospheric formaldehyde ( $\mathrm{HCHO}$ ) is an intermediate product common to the degradation of many volatile organic compounds, and therefore it is a central component of tropospheric chemistry. While the global formaldehyde background is due to methane oxidation, emissions of non-methane volatile organic compounds (NMVOCs) from biogenic, biomass burning and anthropogenic continental sources result in important and localised enhancements of the $\mathrm{HCHO}$ concentration. Improving our knowledge of NMVOC emissions is essential for a better understanding of the processes that control the production and the evolution of tropospheric ozone, a key actor in air quality and climate change, but also of the hydroxyl radical $\mathrm{OH}$, the main cleansing agent of our troposphere. As the lifetime of HCHO is typically a few hours, enhanced concentrations serve as tracers for reactive NMVOC emissions (Fig. 10). Moreover, HCHO satellite observations are used in combination with tropospheric chemistry transport models to constrain NMVOC emission inventories in so-called top-down inversion ap- 
(a)

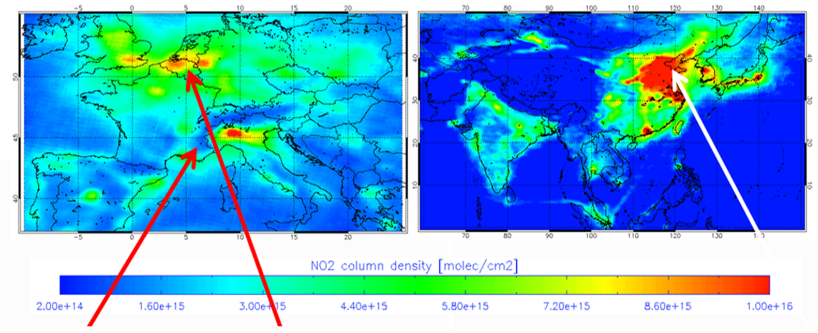

(b)
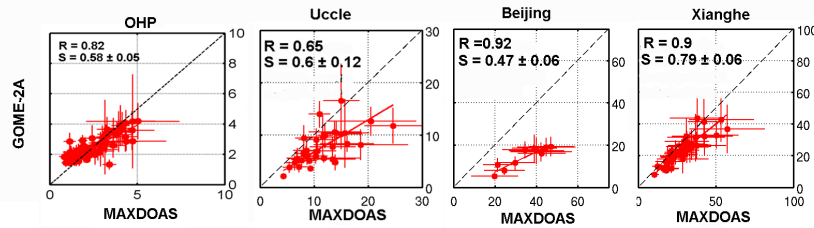

(c)

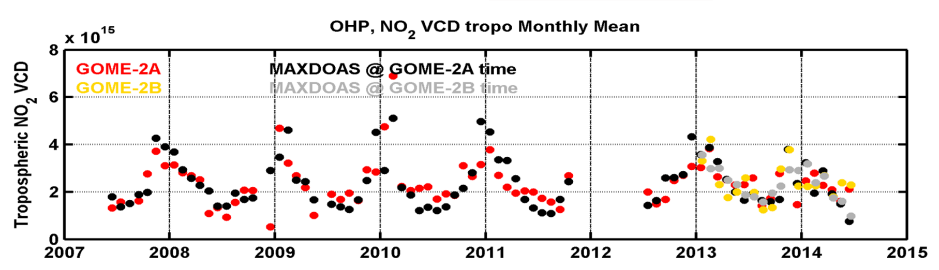

(d)

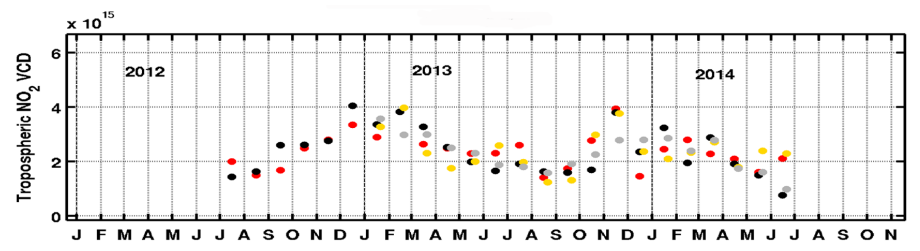

Figure 9. Example of tropospheric $\mathrm{NO}_{2}$ validation: (a) maps of tropospheric $\mathrm{NO}_{2}$ from GOME-2 and the location of three BIRA-IASB MAXDOAS stations: OHP, Uccle and Xianghe. (b) The correlation plots are given for each station for GOME-2A (OHP from June 2007 to June 2014, Uccle from May 2011 to May 2014, Beijing from June 2008 to April 2009, Xianghe from March 2010 to December 2013), (c) a time series of MAXDOAS, GOME-2A and GOME-2B is given for OHP station, and a close-up of the 2012-2014 period is given in (d).

proaches. Satellite $\mathrm{HCHO}$ and $\mathrm{NO}_{2}$ observations are also combined to estimate $\mathrm{VOC} / \mathrm{NO}_{x}$ ratios, and thereby the local chemical regime of tropospheric ozone production. The HCHO retrieval is based on the DOAS technique and follows the developments published in De Smedt et al. (2012). Common settings are used for GOME-2A and GOME-2B retrievals. The HCHO slant column inversion is performed in the UV wavelength range $328.5-346 \mathrm{~nm}$, and includes a post-treatment for systematic biases based on a latitude dependent offset correction. Tropospheric HCHO vertical columns are calculated using air mass factors that depend on the solar and viewing geometries, the surface albedo, cloud fraction and cloud top height (OCRA/ROCINN product), and the $\mathrm{HCHO}$ profile shape which is derived from threedimensional chemical-transport model simulations obtained using the IMAGES model (Stavrakou et al., 2009).

For the validation of the HCHO columns, a step-by-step verification of the operational product against the reference scientific GOME-2 HCHO retrieval algorithm (De Smedt et al., 2012) has been performed in De Smedt et al. (2013) and confirms the validity of the target accuracy of $50 \%$ in polluted conditions (Table 1). An example of this verification is given in Fig. 11 for two different emissions regions: northern China and Amazonia. GOME-2B HCHO slant columns, fit residuals, and scatter are comparable to those obtained from GOME-2A spectra at the beginning of the mission in 2007, both for the operational and scientific products. The effect of Metop-A degradation (increased noise caused by decreased throughput, see Munro et al., 2015) is clearly visible in Fig. 11, with the DOAS fit RMS increase with time for both operational and scientific products. Differences between operational and scientific data sets are within 40 and $28 \%$ for GOME-2A since 2007 and within 20 and $13 \%$ for GOME2B since December 2012, for Amazonia and northern China, respectively. GOME-2 A and B GDP 4.7 HCHO retrievals are in very good agreement with the reference scientific retrievals when using the same settings (not shown here). The reduced HCHO slant column noise level in the scientific algorithm presented here (v14) is obtained by pre-fitting $\mathrm{BrO}$ in a separate larger interval $(328.5-359 \mathrm{~nm})$ which allows decorrelation of $\mathrm{HCHO}$ and $\mathrm{BrO}$ differential absorption structures (De Smedt et al., 2012). Remaining differences between the operational and scientific HCHO vertical columns are mainly related to the different input parameters used for 


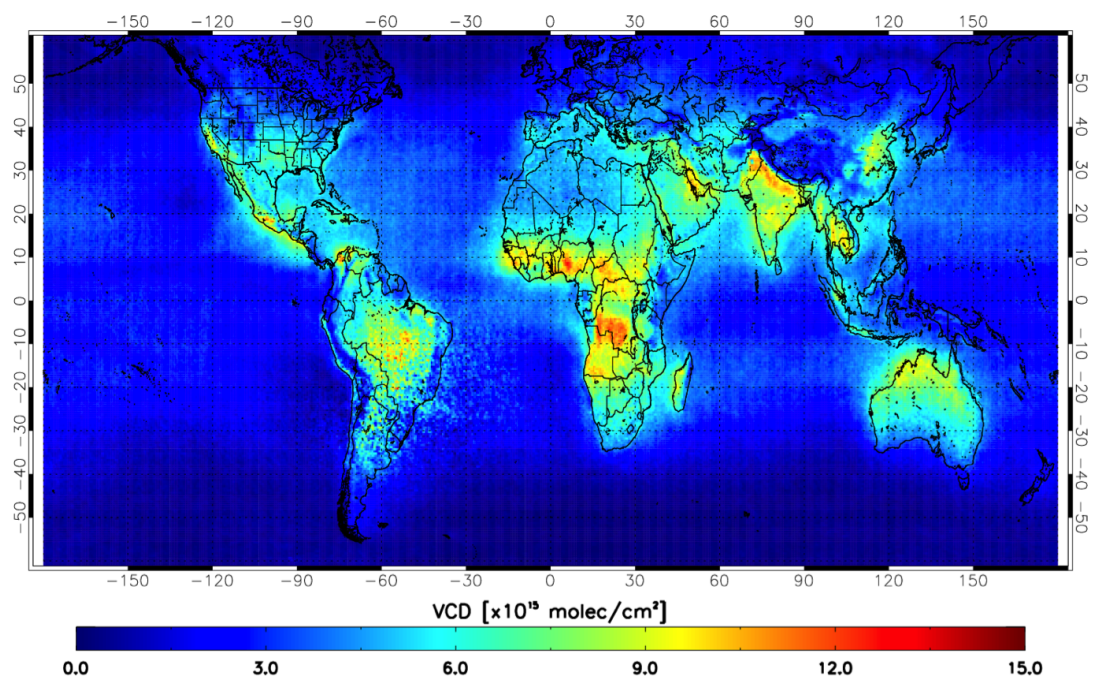

Figure 10. Averaged tropospheric HCHO columns for 2013 as measured by GOME-2B.

the air mass factor calculation, namely the cloud product and the surface albedo. An improved version of the $\mathrm{HCHO}$ operational product addressing both GOME- $2 \mathrm{~A}$ and $\mathrm{B}$ is under preparation based on recent scientific algorithm developments and will be released with the next version of the GDP data product (GDP 4.8). In addition to the verification against the scientific prototype, comparisons with other HCHO satellite data sets, such as GOME, SCIAMACHY and OMI instruments as well as direct comparisons with ground-based MAXDOAS and/or FTIR instruments are planned to be performed in the near future.

The main user of the O3M SAF NRT and reprocessed GOME-2 H2CO products is CAMS (Copernicus Atmosphere Monitoring Service).

\subsection{Total $\mathrm{SO}_{2}$ column}

The main sources for $\mathrm{SO}_{2}$ in the Earth's atmosphere are anthropogenic emissions and volcanic eruptions. During volcanic eruptions, $\mathrm{SO}_{2}$, ash and various gases are emitted into the atmosphere. $\mathrm{SO}_{2}$ is thus a robust indicator for volcanic activity which can serve as a proxy for the potential emission of volcanic ash that is initially collocated with the emitted volcanic $\mathrm{SO}_{2}$. The timely and global measurement of volcanic $\mathrm{SO}_{2}$ can thus provide critical information for aviation hazard mitigation when it is used by the Volcanic Ash Advisory Centers (VAACs) (Carn et al., 2009). Volcanic $\mathrm{SO}_{2}$ has an impact on the local air quality affecting human health and ecosystems and threatening aviation safety since $\mathrm{SO}_{2}$ causes sulfidation in the aircraft engines which might lead to a total engine failure if exposed over a long period of time. Volcanic $\mathrm{SO}_{2}$ also has an effect on the global climate. When released into the atmosphere it is subject to wet and dry decomposition as well as oxidisation to sulfate aerosols (Robock, 2000).
In the lower troposphere $\mathrm{SO}_{2}$ and sulfate aerosols have a lifetime of a few days. When injected into the stratosphere by, e.g. explosive volcanic eruptions, the $\mathrm{SO}_{2}$ lifetime is several weeks, whereas sulfate aerosols can remain for over a year (Forster et al., 2007), affecting the Earth's radiative forcing by reflecting the solar irradiation and by changing the albedo and lifetime of clouds. For example the 1991 Pinatubo eruption caused an average global cooling of about 0.3 $0.5^{\circ} \mathrm{C}$ for years (see e.g. McCormic et al., 1995; Robock, 2000). Global $\mathrm{SO}_{2}$ emissions averaged over the year 2015 are shown in Fig. 12.

The DOAS slant column retrieval of $\mathrm{SO}_{2}$ is performed in the UV wavelength range 315-326 nm (Rix et al., 2012). The retrieved $\mathrm{SO}_{2}$ slant columns are corrected for any systematic bias by applying a latitude and surface-elevation dependent offset correction. Total vertical $\mathrm{SO}_{2}$ columns are calculated by applying an air mass factor which depends on the viewing geometry surface conditions and the $\mathrm{SO}_{2}$ profile shape. Since at the time of the measurement the $\mathrm{SO}_{2}$ plume height is unknown, the total vertical column is calculated for three scenarios: the passive degassing of volcanoes and anthropogenic pollution (plume height: $2.5 \mathrm{~km}$ ); passive degassing of high altitude volcanoes and weak eruptions $(6 \mathrm{~km})$; and explosive volcanic eruptions $(15 \mathrm{~km})$. Furthermore, in order to detect volcanic eruptions, pixels with elevated $\mathrm{SO}_{2}$ columns are automatically flagged when they fulfill certain threshold criteria (Brenot et al., 2014). This is especially important for the assimilation of the GOME-2 $\mathrm{SO}_{2}$ columns in forecast models, such as in the CAMS system. Note that this flag will be provided to the users with the release of the next version of the $\mathrm{SO}_{2}$ product (GDP4.8), which will be released in early 2016 .

The validation of GOME- $2 \mathrm{SO}_{2}$ columns currently relies on inter-comparisons with other satellite data sets, such as SCIAMACHY/Envisat and OMI/Aura as well as interevaluation between the two GOME-2 instruments. The cur- 
(a)
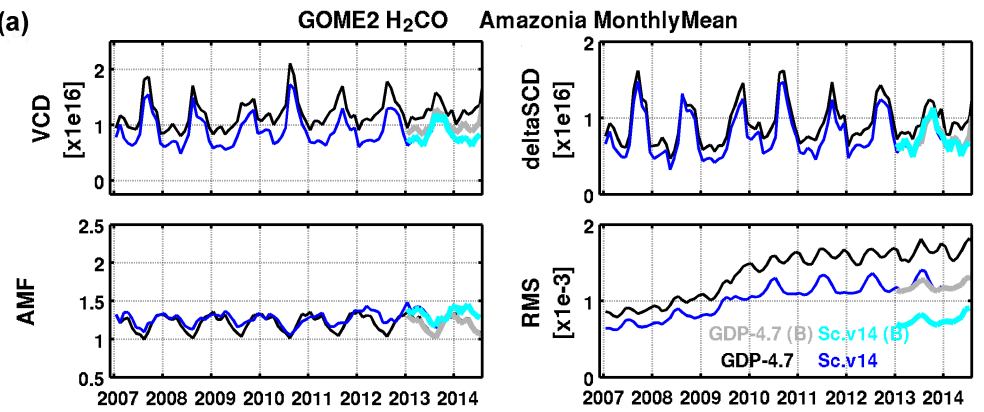

(b)
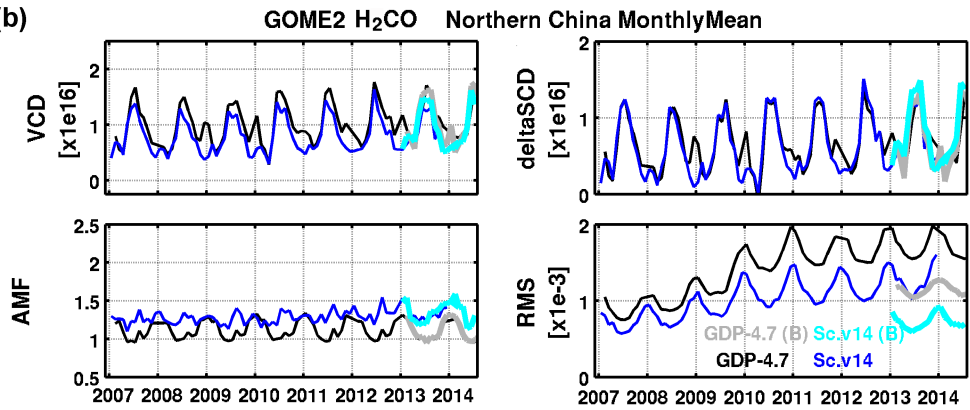

Figure 11. Example of HCHO end-to-end validation for (a) the Guatemala and (b) northern China regions. Monthly means comparisons of GOME-2A and GOME-2B GDP data (black and grey) are compared to the corresponding scientific algorithm v14 (blue and cyan) for every step of the VCD retrieval: the normalised slant columns (delta SCD), the DOAS fit RMS (indicator of the fit quality), the cloud-corrected (total tropospheric) air mass factor AMF and the tropospheric vertical column VCD.

rent comparisons show that the GOME- $2 \mathrm{SO}_{2}$ data are within the $50 \%$ target accuracy (Table 1). An example of an intercomparison of GOME-2A and GOME-2B for the Copahue volcanic eruption on the 23 December 2012 is given in Fig. 13, left, showing very consistent results between the two sensors for their co-located measurements. Figure 13, right, shows an example of anthropogenic $\mathrm{SO}_{2}$ comparisons, for a region in Eastern China centralised over Beijing. The OMI/Aura PBL (planetary boundary layer) product (Version 003, $\mathrm{Li}$ et al., 2013) which assumes an $\mathrm{SO}_{2}$ loading with a centre of mass altitude of about $0.9 \mathrm{~km}$ ( $\mathrm{Li}$ et al., 2013), is compared to both GOME-2A and GOME-2B observations considering an $\mathrm{SO}_{2}$ plume height at $2.5 \mathrm{~km}$. A very good correlation between GOME-2A and $\mathrm{B}$ results is shown in the scatter plot (blue line) with $r$-squared of 0.74 , to be expected since the same algorithm is applied to both sensors. However, the GOME-2B retrievals result in lower $\mathrm{SO}_{2}$ columns than the OMI retrievals for loadings over $0.5 \mathrm{DU}$ as shown in the equivalent scatter plot (red line), even though the absolute correlation is very satisfactory at 0.80 . The reason for this difference may be attributed to the different assumptions on the a priori $\mathrm{SO}_{2}$ profile used by the two different algorithms (see Theys et al., 2013b, for more details). In the future, comparisons with ground-based MAXDOAS instruments at different global locations are envisaged for strong anthropogenic and volcanic $\mathrm{SO}_{2}$ cases as this type of comparison allows the dependence of the retrievals on the $\mathrm{SO}_{2}$ profile shape to be taken into account.
The main users of the GOME-2 $\mathrm{SO}_{2}$ product are the volcanic hazard and air quality communities. The GOME- $2 \mathrm{SO}_{2}$ product is used within the Support to Aviation Control Service (SACS) (Brenot et al., 2014), that provides volcanic plume information to the Volcanic Ash Advisory Centers (VAACs) and other users. The GOME-2 $\mathrm{SO}_{2}$ columns are also used within the GMES service EVOSS, which monitors volcanic activity and relevant hazards at a global scale using Earth observation data products. Furthermore, the GOME-2 $\mathrm{SO}_{2}$ columns have been used within the mobile volcano fast response system Exupéy (Rix et al., 2009).

\subsection{Total BrO column}

$\mathrm{BrO}$ is present in the lower stratosphere, where it depletes ozone through very efficient catalytic reactions. $\mathrm{BrO}$ is also released in the troposphere from sea ice, at the interface of ocean, salt lakes and volcanoes.

The retrieval of total $\mathrm{BrO}$ is achieved by a DOAS analysis in the wavelength region 332-359 nm (Theys et al., 2011), including five $\mathrm{BrO}$ absorption bands. It is followed by an equatorial offset correction (Richter et al., 2002) applied to the retrieved slant columns, in order to minimize the impact of the long-term instrumental degradation. The conversion into total $\mathrm{BrO}$ vertical columns is made using air mass factors assuming representative stratospheric $\mathrm{BrO}$ profiles. The main interest is on bromine emissions in the polar boundary layer. GOME-2 measurements allow springtime $\mathrm{BrO}$ columns to 


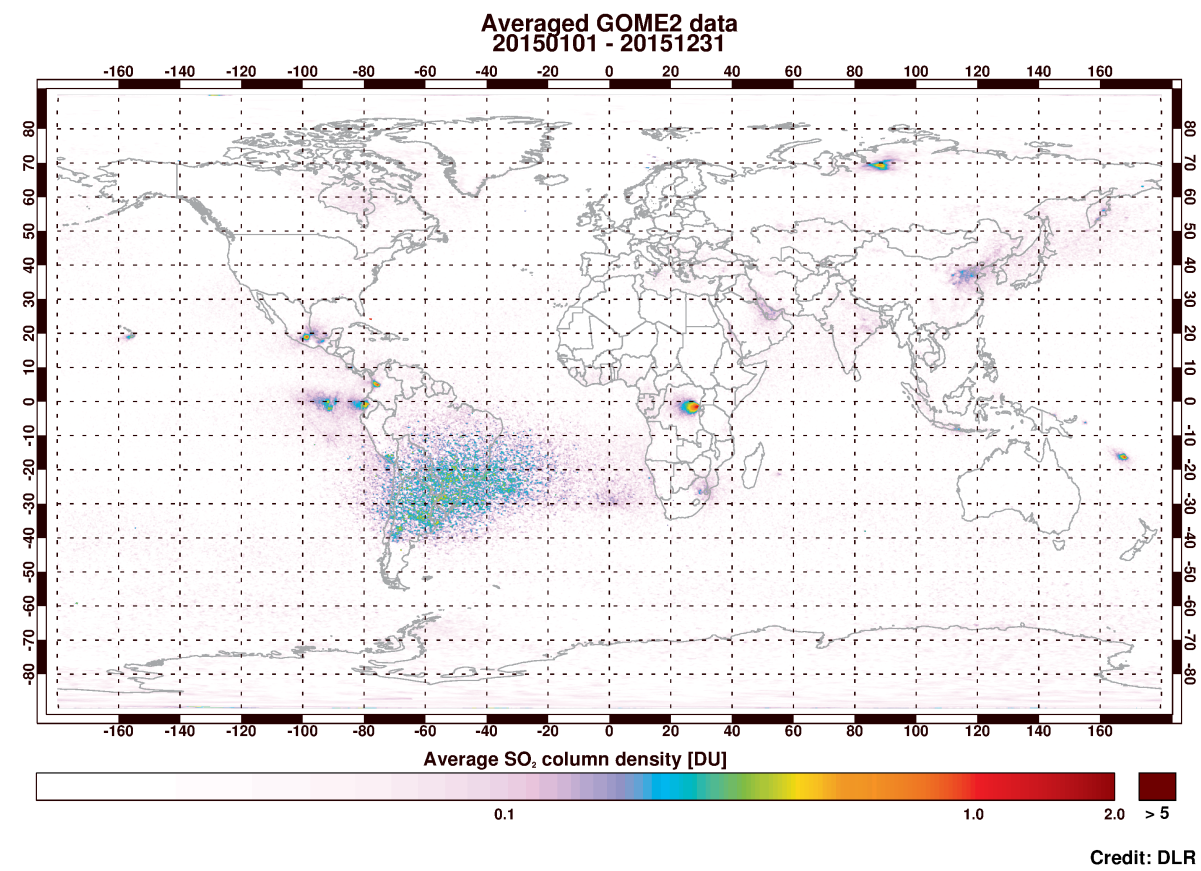

Figure 12. Global $\mathrm{SO}_{2}$ emissions detected by GOME-2A and GOME-2B, averaged over 2015. Clearly visible are the year 2015 volcanic eruptions of Wolf volcano (Galapagos Islands), Cotopaxi and Tungurahua (Ecuador), Ubinas (Peru), the active volcanoes Popocatépetl (Mexico), Nyamuragira/Nyiragongo (Congo), Ambrym (Vanuatu), as well as anthropogenic pollution areas in Norilsk (Russia), Bohai (China), South Africa and in the Persian Gulf.

(a)

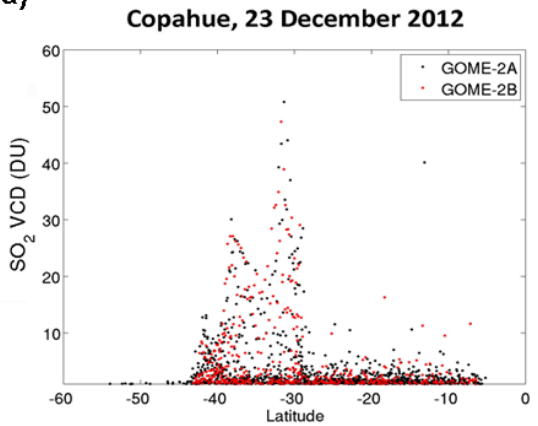

(b)

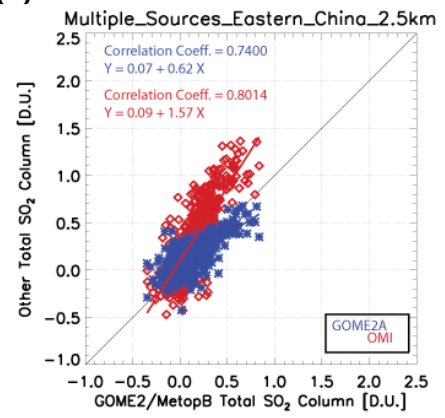

Figure 13. Example of $\mathrm{SO}_{2}$ validation activities: (a) comparisons of $\mathrm{SO}_{2}$ columns retrieved from GOME-2A and GOME-2B for the Copahue eruption, as a function of latitude and (b) scatter plot of anthropogenic $\mathrm{SO}_{2}$ (assuming a $2.5 \mathrm{~km}$ plume height ) over eastern China from GOME-2B ( $x$ axis) and, respectively, GOME-2A (blue) and OMI (red).

be studied in both the Arctic and Antarctic regions (as illustrated in Fig. 14). BrO production is related to heterogeneous photochemistry due to the presence of sea salt, but the mechanisms are currently not fully characterized, especially the link with meterological variables (e.g. wind) and the importance of bromine for the deposition of mercury which impacts the polar biosphere. Owing to its wide coverage, GOME-2 measurements enable long-range transport of polar tropospheric $\mathrm{BrO}$ (Begoin et al., 2010) to be studied, and also emissions from volcanic eruptions (Theys et al., 2009a; Hörmann et al., 2013). In addition there is an interest in the study of stratospheric $\mathrm{BrO}$ and its long-term trend. However, strictly speaking, scientific studies of $\mathrm{BrO}$ from GOME-2 measurements are only possible by separating the retrieved total $\mathrm{BrO}$ column into its tropospheric and stratospheric components (see Sect. 6).

The validation of $\mathrm{BrO}$ columns relies on the comparison of the total columns to other satellite data sets, such as the SCIAMACHY and GOME-2 scientific products (Theys et al., 2011) and on ground-based zenith-sky DOAS instruments from NDACC stations, such as Harestua (Hendrick et al., 2007). The results for the validation of GOME-2A and $\mathrm{B} \mathrm{BrO}$ total columns can be found in Theys et al. (2013a) and on the O3M SAF BIRA validation pages (http: 


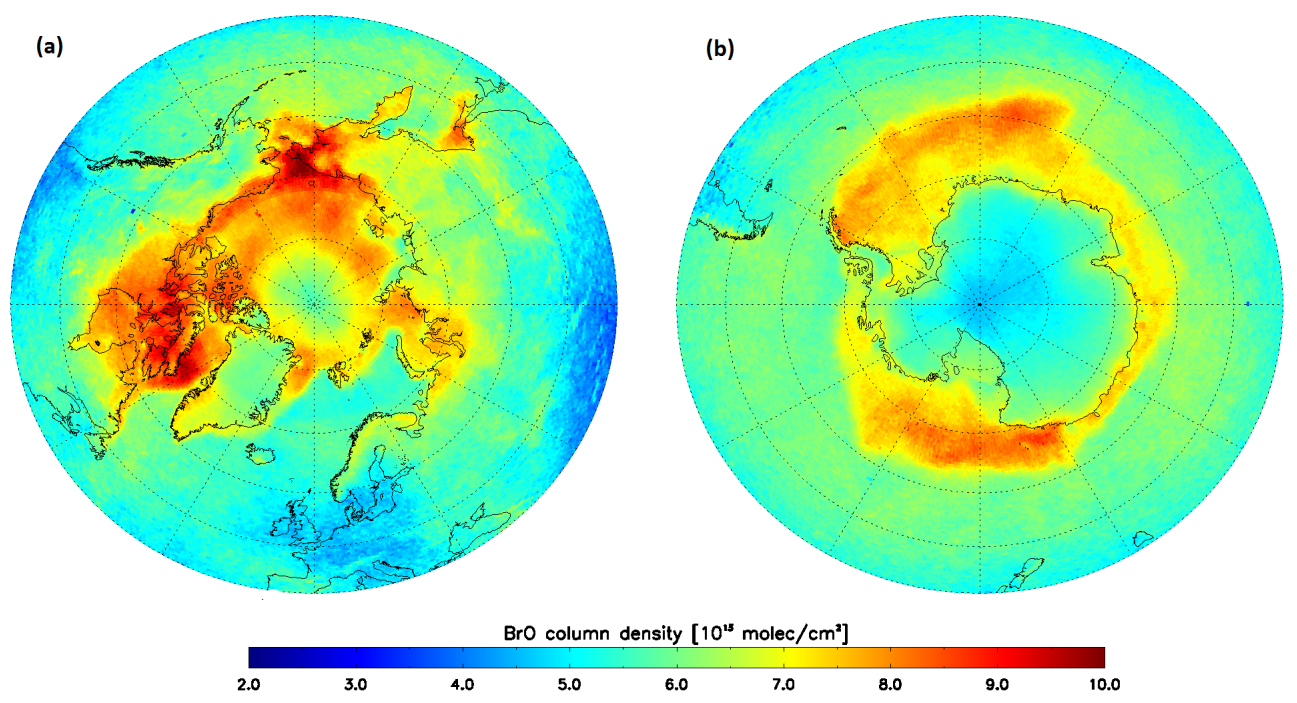

Figure 14. Monthly averaged total BrO columns (a) over the Arctic, April 2007 and (b) Antarctic, October 2007.

//cdop.aeronomie.be/validation/valid-results). Examples are shown in Fig. 15. One can see that the satellite columns are very consistent with each other at all latitudes and seasons. The comparison of GOME-2A and GOME-2B with groundbased $\mathrm{BrO}$ columns at Harestua is also good for the absolute values and for the short-term variation of the $\mathrm{BrO}$ total column. The conclusion is that the GOME-2A and -B total $\mathrm{BrO}$ columns have an accuracy better than $30 \%$ most of the time and hence the product reaches its target accuracy.

\subsection{Total water vapour column}

Atmospheric water vapour plays a major role for meteorology as well as for climate because it is an important greenhouse gas (Solomon et al., 2000) and via its influence on the formation of clouds and precipitation and the growth of aerosols (Hegg and Baker, 2009). Hence, advancing in understanding of variability and long-term changes in water vapour is vital, especially considering that atmospheric water vapour exhibits a highly variable spatial and temporal distribution. Total column water vapour (TCWV) from GOME-2 is the only data product with the following combination of features: global coverage over land and over sea, good sensitivity down to the surface (where most of the water vapour column resides), independent of model input (no model-dependent information in climatological data record), and retrievals insensitive to instrument drift. Thus, the GOME-2 water vapour product is especially valuable for long-term series and climatological studies (Wagner et al., 2006; Lang et al., 2007; Noël et al., 2008; Mieruch et al., 2010). The example of the retrieved monthly mean maps of total column water vapour in Fig. 16 shows the global distribution of TCWV in February and August 2008 retrieved by GOME-2A. The algorithm used for the retrieval of GOME2 TCWV is based on a classical differential optical absorp- tion spectroscopy (DOAS) performed in the wavelength interval 614.0-683.2 $\mathrm{nm}$ and does not include explicit numerical modelling of the atmospheric radiative transfer (Wagner et al., 2006; Grossi et al., 2015). It consists of three basic steps: in the first step, the spectral DOAS fitting is carried out, taking into account absorption by $\mathrm{O}_{2}$ and $\mathrm{O}_{4}$, in addition to that of water vapour. In the second step, a correction for absorption non-linearity effects is applied because the highly fine-structured $\mathrm{H}_{2} \mathrm{O}$ (and $\mathrm{O}_{2}$ ) absorption bands cannot be spectroscopically resolved by the GOME- 2 instrument. In the last step, the corrected water vapour slant columns determined with the DOAS fitting are converted to geometryindependent vertical column densities (VCDs) through division by an appropriate air mass factor (AMF), which is derived from the measured $\mathrm{O}_{2}$ absorption.

To assess the quality of the GOME-2 water vapour columns, the TCWV products were compared with corresponding model data from the European Centre for Medium Range Weather Forecast (ECMWF) ERA-Interim reanalysis (Dee et al., 2011) and with SSMIS satellite F16 measurements (Wentz and Meissner, 2007) during the full period January 2007-June 2014 (Grossi et al., 2015). A comparison between the GOME-2A product and the combined SSM/I + MERIS GlobVapour data set in 2007 and 2008 was also carried out. Good general agreement was reported between all three data sets with mean bias within $0.035 \mathrm{~g} \mathrm{~cm}^{2}$, although some seasonal and regional biases have been identified. Figure 17 shows a time series of globally averaged total bias in the TCWV distribution between GOME-2A and the data sets described above. Since January 2013, the bias between the most recent GOME-2B results and the ERAInterim and SSMIS retrievals was also computed. It was found that the combined SSM/I - MERIS sample and the ERA-Interim data set are typically drier than the GOME-2 
(a)

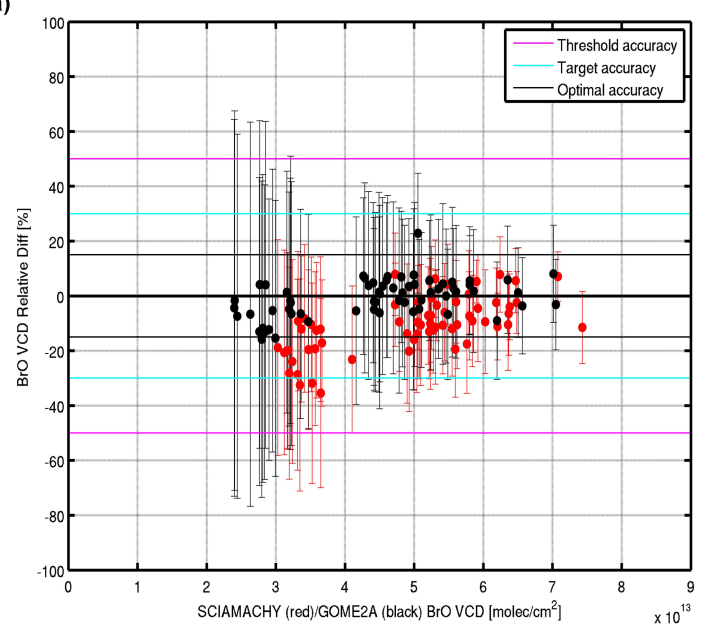

(b)
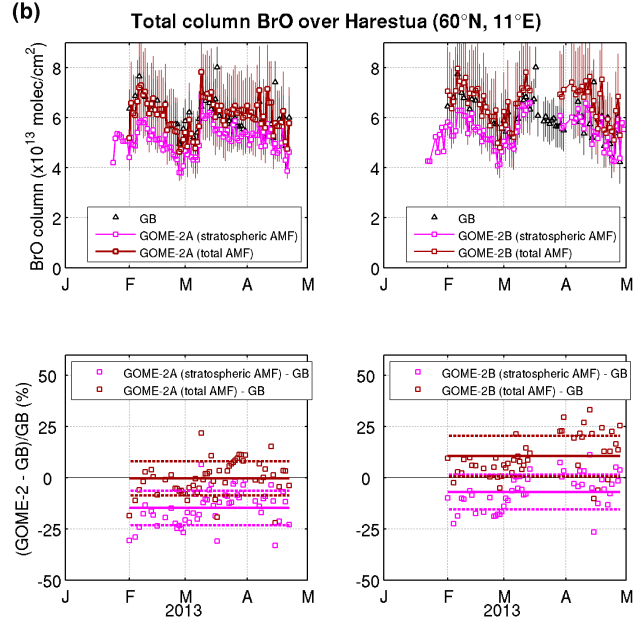

Figure 15. Example of BrO validation: (a) Monthly averaged BrO VCD relative difference between GOME-2B (red) and GOME-2A (black) against SCIAMACHY as a function of SCIAMACHY/GOME-2A BrO VCD, for 14 sites from pole-to-pole over the period December 2012April 2013. (b) Comparison of GOME-2 (A and B) and ground-based total BrO columns at Harestua $\left(60^{\circ} \mathrm{N}, 11^{\circ} \mathrm{E}\right)$ in February-April 2013. The satellite results labelled "total AMF" are calculated using the stratospheric and tropospheric AMFs weighted by the BrO column contribution in both layers as retrieved from the ground-based measurements. The relative differences (squares) and mean biases (solid lines) appear in the lower plots. The number of coincidences is 55 for GOME-2A and 49 for GOME-2B.

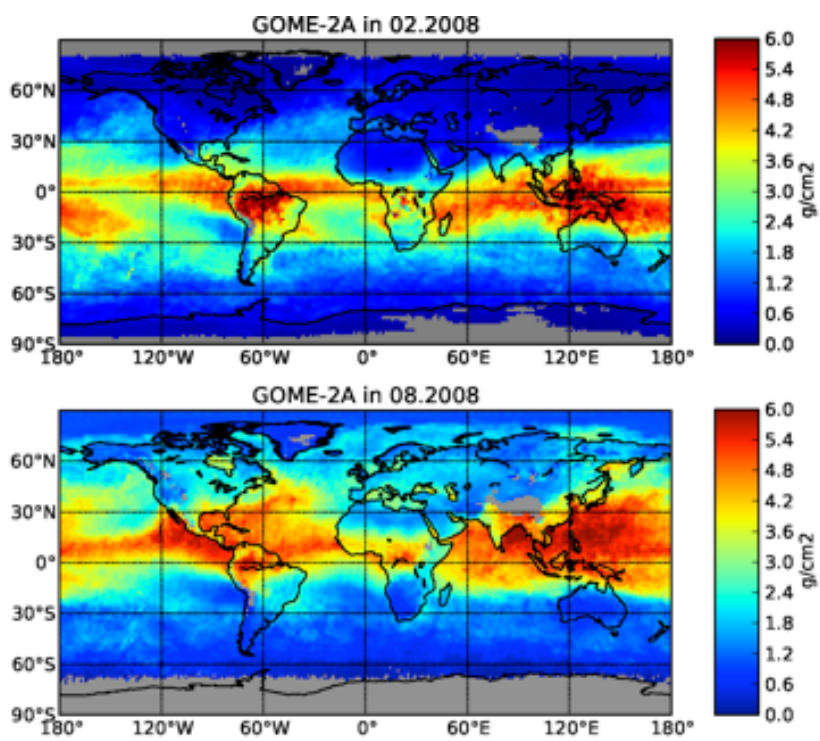

Figure 16. Monthly mean maps of total column water vapour from GOME-2A for February 2008 (on the top) and August 2008 (on the bottom). Only cloud-screened data have been used.

retrievals $\left(0.032\right.$ and $0.035 \mathrm{~g} \mathrm{~cm}^{-2}$, respectively), while on average GOME-2 data overestimate the SSMIS measurements by only $0.006 \mathrm{~g} \mathrm{~cm}^{-2}$. However, the size of these biases is seasonally dependent. Monthly average differences as large as $0.1 \mathrm{~g} \mathrm{~cm}^{-2}$ were observed in the analysis against SSMIS measurements, but were not so evident in the comparison with ERA/Interim and SSM/I + MERIS data, because of the compensating effect of having land and ocean retrievals.
Pronounced negative biases over land areas were identified in regions with high humidity or a relatively large surface albedo (0.3-0.5).

The water vapour product has also been validated against ground-based data (Kalakoski et al., 2014). In that study, the radiosonde data were from the Integrated Global Radiosonde Archive (IGRA) maintained by National Climatic Data Center (NCDC) and screened for soundings with incomplete tropospheric column, whereas the ground-based GPS observations from COSMIC/SuomiNet network were used as the second independent data source. The outcome described in the paper was that the general agreement between GOME-2 and the ground-based observations is good. The median relative difference to radiosonde observations was found to be $-2.7 \%$ for GOME-2A and $-0.3 \%$ for GOME-2B. Against GPS observations, the median relative differences were 4.9 and $3.2 \%$ for GOME-2A and B, respectively. For water vapour total columns below $10 \mathrm{~kg} \mathrm{~m}^{-2}$, large wet biases were observed, especially against GPS observations. Conversely, at values above $50 \mathrm{~kg} \mathrm{~m}^{-2}$, GOME-2 generally underestimates both ground-based observations.

\subsection{Aerosol products}

The Absorbing Aerosol Index (AAI) product is derived from the reflectances measured by GOME- 2 at 340 and $380 \mathrm{~nm}$ (Tilstra et al., 2010). The AAI may be used to detect absorbing aerosols over both land and sea surfaces, even in the presence of clouds. The AAI retrieval algorithm compares the measured reflectances with simulated clear-sky reflectances and calculates a residue from these which represents the dif- 


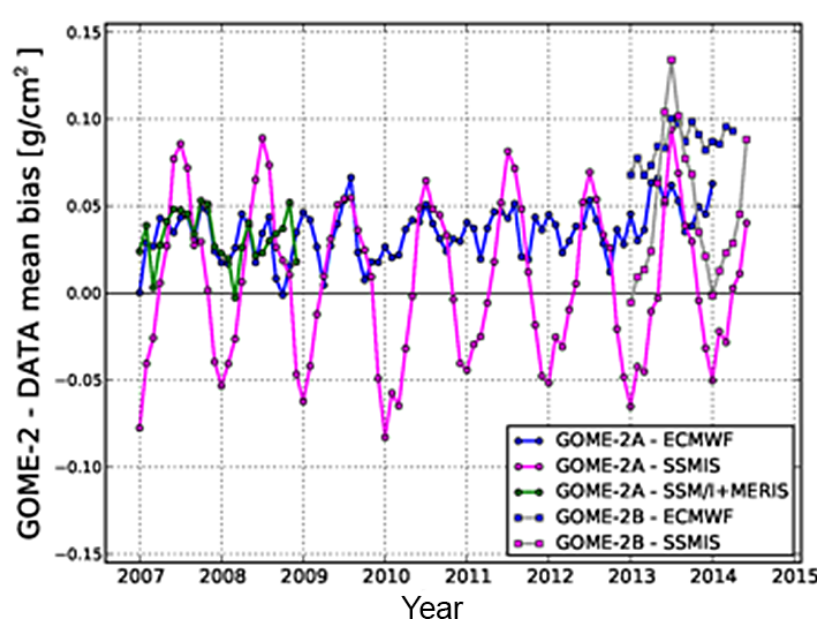

Figure 17. Global monthly mean bias between GOME-2A and 3 independent TCWV data sets for the period January 2007-June 2014, depending on availability of the reference data. The comparison is performed against ECMWF ERA-Interim reanalysis (blue points), SSMIS F16 satellite (magenta points, only over ocean) and combined SSM/I + MERIS data set (green points). Coloured squares and gray lines show the bias between the most recent GOME-2B observations and the ECMWF and SSMIS data sets.

ference between measurement and (clear-sky) simulation and takes the form of a single index.

A high radiometric stability of the Level-2 product is extremely important for the AAI data record as a whole, because the AAI is very sensitive to changes in the radiometric calibration of the instrument. Before calculating the AAI from the Earth reflectances, the reflectances are first corrected for the effects of instrument degradation. For this preprocessing correction we make use of the method introduced in Tilstra et al. (2012a) for the SCIAMACHY instrument that was later applied to the GOME-2 instrument (Tilstra et al., 2012b). This correction for instrument degradation is a function of time, wavelength and scan mirror position, and it is instrument-specific. After application of the correction, the errors caused by instrument degradation are removed to within 0.1 index point over the entire time period covered by the satellite.

In the algorithm, the surface albedo is assumed to be constant over the spectral range of the two selected wavelengths, and when the total ozone column is taken into account in the simulations, deviations from the Rayleigh scattering atmosphere are caused purely by clouds and/or aerosols. Negative values for the AAI are caused by the presence of clouds and/or scattering aerosol in the scene. However, a positive value for the AAI can only be explained by the presence of absorbing aerosols. This makes the AAI ideally suited for aerosol masking and the detection of smoke from forest fires or volcanic eruptions. An example of the detection of a volcanic plume is shown in Fig. 18, where the ash plume originating from the Puyehue volcano can be seen to travel from

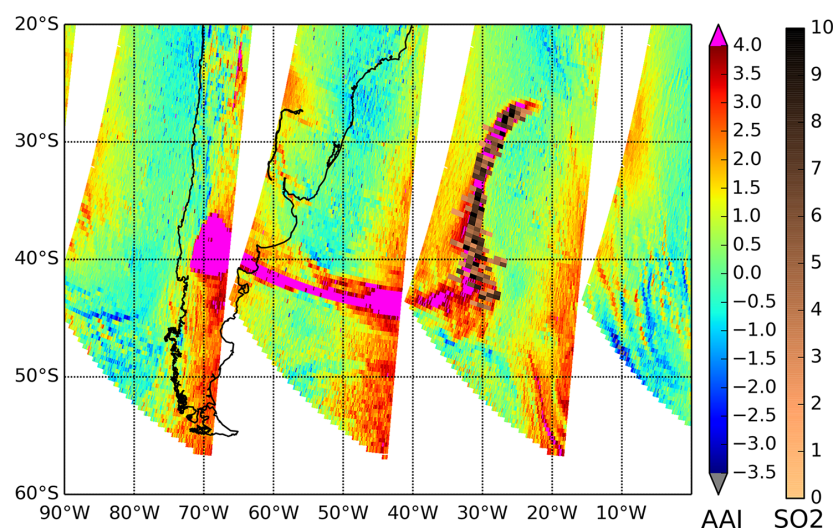

Figure 18. Absorbing aerosol index from the PMD bands from GOME-2A on 6 June 2011 over the south Atlantic Ocean. The plume of aerosol originates from an eruption of the Puyehue volcano. The GOME-2A SO 2 data are plotted over the AAI values to show how the AAI and $\mathrm{SO}_{2}$ products see the dispersions of the volcanic ash and $\mathrm{SO}_{2}$ clouds, respectively. The $\mathrm{SO}_{2}$ values are in Dobson Units with a different colour scale.

its source eastward over the south Atlantic Ocean. This event has been analysed in Wang et al. (2012).

For the validation of the GOME-2 AAI product we rely on comparisons with AAI products derived from other satellite instruments, such as GOME-1, SCIAMACHY and OMI. The validation results show that the GOME-2 AAI has reached the target accuracy of 0.5 index point (Tilstra et al., 2013). Since the launch of Metop-B, the AAI products from GOME-2A and GOME-2B can be compared, and the global means of the two AAI products are nearly identical, with GOME-2B having AAI values on average 0.2 index points higher than GOME-2A. Both AAI products meet the target requirements. More detailed validation results can be found in the mentioned validation report.

\subsection{Lambertian-equivalent reflectivity surface albedo database}

The Lambertian-equivalent reflectivity (LER) of the Earth's surface is based on reflectance measurements taken by GOME-2A. It is the improved follow-up of earlier surface LER databases based on GOME-1 (on the ERS-2 satellite) and OMI (on the Aura satellite). As a result of this, the algorithm was influenced strongly by the approaches followed for the GOME-1 surface LER database (Koelemeijer et al., 2003) and the OMI surface LER database (Kleipool et al., 2008). The surface LER is an essential input parameter for the retrieval of many trace gases, cloud properties and aerosols.

The GOME-2 surface LER is retrieved from the main science channels for 15 pre-defined $1 \mathrm{~nm}$-wide wavelength bands ranging from the UV to the near-infrared. Additionally, we provide a surface LER product based on the PMD 


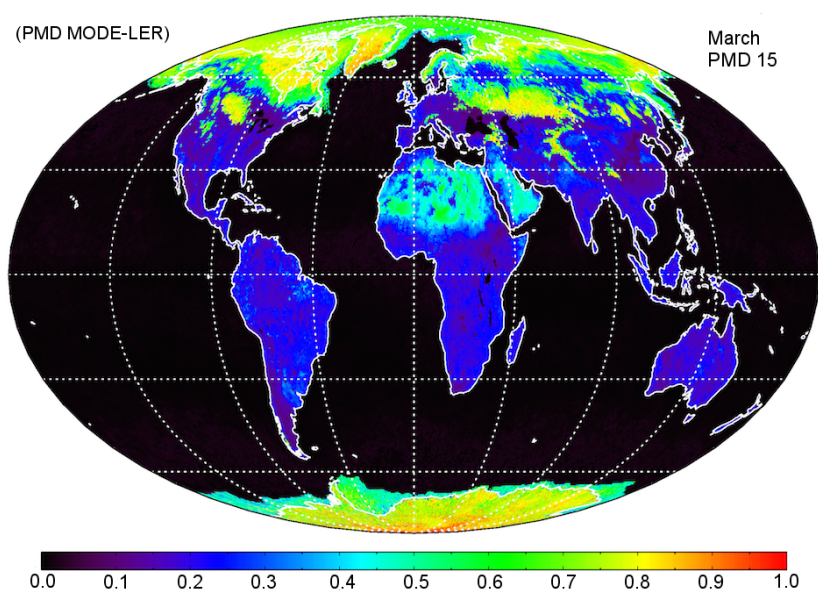

Figure 19. Example of the GOME-2 surface LER determined from PMD band 15 (centred around $799 \mathrm{~nm}$ ) for March. The snow cover on northern latitudes as well as the Sahara are clearly seen.

(polarisation measurement device) measurements. The definition of these PMD bands is fixed but the advantage is the much smaller footprint size $(10 \mathrm{~km} \times 40 \mathrm{~km}$ instead of $80 \mathrm{~km} \times 40 \mathrm{~km}$ ) which results in better statistics. The surface LER spectra are provided for each month of the year in a grid of $1^{\circ} \times 1^{\circ}\left(\right.$ MSC-LER) or $0.5^{\circ} \times 0.5^{\circ}$ (PMD-LER).

The retrieval algorithm follows an approach in which the reflectance measurements from the entire mission are transformed for each of the months into scene LERs. The scene LERs are distributed into the grid cells of the Earth grid and their histograms are analysed to find the representative (cloud-free) scene LER, i.e. the spectral surface LER. For some surfaces the mode of this distribution is taken (e.g. snow, desert), for others the minimum value is taken (e.g. ocean). Cloud contamination over the oceans caused by persistent cloud presence is corrected by looking for near-by grid cells that can act as a surface LER donor. The surface LER is retrieved for land and sea surfaces, including those covered by snow and ice.

Artificial trends in the Earth reflectances due to instrument degradation are removed before the actual surface LER retrieval starts. The method that is used is described in Sect. 5.8. A more extensive description of the algorithm and the products can be found in Tilstra et al. (2014). An example of the surface LER product is presented in Fig. 19.

\subsection{UV radiation products}

Offline surface ultraviolet (UV) radiation products (OUVs) contain the most important quantities of the solar radiation that can be harmful to life and materials on the Earth. These quantities include daily doses and maximum dose rates of integrated UVB and UVA radiation together with values obtained by different biological weighting functions, solar noon UV index and quality control flags. Recent additions are

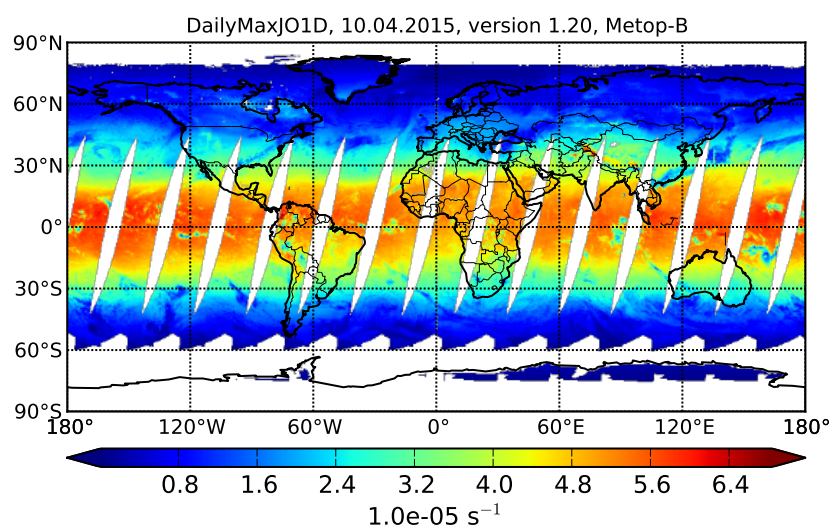

Figure 20. Daily maximum photolysis frequency of ozone $j_{\mathrm{O}^{1} \mathrm{D}}$ at the ground level obtained from Metop-B and NOAA-19 data on 10 April 2015. Global coverage of the product is limited by the swath of the GOME-2 instrument leaving stripes at low latitudes. The polar night and the maximum solar zenith angle for cloud processing limit the coverage at high latitudes while cloud-free values are accepted for the Antarctic and Greenland ice sheets.

the photolysis frequencies of two key reactions in the atmospheric chemistry of the troposphere: the photodissociation of ozone and nitrogen dioxide. The photolysis frequency of ozone refers to the rate constant $j_{\mathrm{O}\left({ }^{1} \mathrm{D}\right)}$ of the following reaction forming atomic oxygen in its exited ${ }^{1} \mathrm{D}$ state from ozone

$\mathrm{O}_{3}+h v(\lambda<320 \mathrm{~nm}) \rightarrow \mathrm{O}\left({ }^{1} \mathrm{D}\right)+\mathrm{O}_{2}$.

This is an important photodissociation route of ozone leading to production of the hydroxyl radical, a key species in oxidation of hydrocarbons in the troposphere. Figure 20 shows, as an example, the daily maximum $j_{\mathrm{O}\left({ }^{1} \mathrm{D}\right)}$ at ground level on 10 April 2015.

The OUV products are derived from the O3M SAF total ozone column product and the visible channel reflectances of the third Advanced Very High Resolution Radiometer (AVHRR/3), therefore combining data from two different instruments aboard the Metop satellites (Kujanpää and Kalakoski, 2015). Sampling of the diurnal cloud cycle is improved by complementing the morning orbit Metop AVHRR/3 data with corresponding afternoon orbit data from the Polar Orbiting Environmental Satellites (POES) of the National Oceanic and Atmospheric Administration (NOAA), available through the data exchange between EUMETSAT and NOAA in their Initial Joint Polar System (IJPS) programme. The offline UV products are currently used by research institutes in Europe and Australia and the main interest is in health and long-term applications.

The near-real-time UV product is a $1-5$ day forecast of UV index on global scale. The NUV/CLEAR product is based on GOME-2 assimilated total ozone (ATO) from KNMI. The UV index is calculated from ATO applying climatologies for surface albedo, aerosol optical depth etc. The final NUV/CLEAR index is valid for clear-sky conditions at lo- 


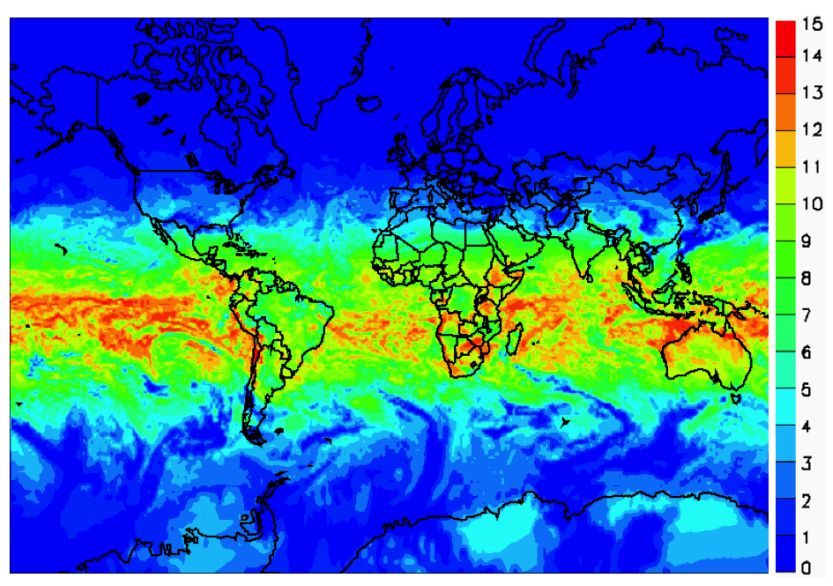

Figure 21. Global map of the NRT cloud-corrected UV index on 2 November 2013.

cal noon, i.e. minimum solar zenith angle, thus reflecting the maximum UV index to be expected for the current day. The NUV/CLOUD product is the NUV/CLEAR product modified with an algorithm using the cloud cover fraction forecast from ECMWF to reflect the actual UV index. The UV fields are calculated on the same grid size as the input ATO fields, with a sub-pixel resolution of $0.25^{\circ} \times 0.25^{\circ}$. The product may be highly customised for users, with regard to geographical coverage, forecast time etc. The users are National Meteorological Institutes as well as news groups for radiation warnings.

The NUV/CLEAR and NUV/CLOUD have been validated against ground-based measurements of UV index. The most recent validation was performed on data from 2011 for six locations with a total of 2064 measurements (JønchSørensen, 2012). In Fig. 21 the distribution of the difference between measured and forecasted NUV/CLOUD product is shown. The red line is the mean and the blue line the median of the distribution. The mean absolute relative difference is $22.6 \%$ for the whole NUV/CLOUD comparison, while the NUV/CLEAR product shows a mean absolute relative difference of $8.5 \%$

\section{Emerging products}

The most of the existing O3M SAF GOME-2 L2 products will be reprocessed in 2016 in order to provide a consistent homogeneous data set to users that is based on the latest state of the art algorithm.

The O3M SAF has recently released new tropospheric ozone products. Furthermore, tropospheric BrO, glyoxal ( $\mathrm{CHOCHO}$ ), $\mathrm{OClO}$ and monthly climate products of $\mathrm{H}_{2} \mathrm{O}$ and $\mathrm{NO}_{2}$ and absorbing aerosol height will be released in 2016.

There are two different kinds of tropospheric ozone products. The first one is a product called tropical tropo- spheric ozone columns (TTOCs) using a convective-clouddifferential (CCD) method (Valks et al., 2014). The retrieval is based on total ozone and cloud property data provided by the GDP 4.8 (see Sect. 3.1), and uses above-cloud and clear-sky ozone column measurements to derive a monthly mean TOC between $20^{\circ} \mathrm{N}$ and $20^{\circ} \mathrm{S}$. Tropical tropospheric ozone data from GOME-2 will provide significant input for climate services and international assessment reports, such as the UNEP/WMO Scientific Assessments of Ozone Depletion and the Climate Assessment Reports of IPCC. The second tropospheric ozone product is based on the separation of the tropospheric and stratospheric columns from the retrieved vertical ozone profiles by splitting the atmosphere at the tropopause and adding the partial ozone columns below and above it.

Satellite total $\mathrm{BrO}$ columns sometimes exhibit strong stratospheric enhancements of $\mathrm{BrO}$, making the interpretation of the results difficult (Theys et al., 2009b; Salawitch et al., 2010). In the frame of the O3M SAF, it is planned to produce tropospheric $\mathrm{BrO}$ columns following the approach developed by Theys et al. (2011) The retrieval of tropospheric BrO columns is achieved through a stratospheric correction based on a $\mathrm{BrO}$ climatology that accounts for the important dynamical and photochemical variations of stratospheric BrO (Theys et al., 2009b). The algorithm also treats the changes in sensitivity in both tropospheric and stratospheric layers. By separating the large-scale $\mathrm{BrO}$ structures (of tropospheric or stratospheric origin) in the total $\mathrm{BrO}$ field, the method allows the polar emissions hotspots and global free-tropospheric $\mathrm{BrO}$ background to be better studied.

Glyoxal (CHOCHO) is a short-lived volatile organic compound (VOC) produced in the atmosphere mostly via the oxidation of other non-methane VOCs emitted by natural and human activities, but also directly emitted by fire events and combustion processes (Fu et al., 2008; Stavrakou et al., 2009). Observations of glyoxal atmospheric concentrations are therefore useful to further constrain estimates of VOC emissions and also to improve the global budget of secondary organic aerosols, for which it has been recognised as an important source (Hallquist et al., 2009). Glyoxal has three absorption bands ranging between 420 and $460 \mathrm{~nm}$, which may be exploited for detection based on the DOAS technique. It has been observed for the first time from space by the SCIAMACHY instrument aboard Envisat (Wittrock et al., 2006). Since then, the GOME-2A data have also been used to retrieve glyoxal tropospheric columns by different teams (Lerot et al., 2010; Vrekoussis et al., 2010). Glyoxal retrievals from space are particularly challenging owing to the weakness of its typical atmospheric optical depth, which leads to strong interferences with other species absorbing in this spectral range. In particular, significant spectral interferences occur with liquid water absorption over remote oceanic areas. Lerot et al. (2010) designed an original 2-step fit method to limit the impact of these interferences. This scientific algorithm will be used as the baseline for implement- 
ing an operational tropospheric glyoxal product as part of the O3M SAF activities in the next 2 years.

The OClO slant column (in molec $\mathrm{cm}^{-2}$ ) measurements will be available under chlorine activated ozone hole conditions. Retrieval is only possible under twilight conditions because this molecule is destroyed in full daylight. The algorithm is based on the classical DOAS method. Slant columns of $\mathrm{OClO}$ are derived from the differential absorption structures in a spectral region from 365 to $389 \mathrm{~nm}$.

Climate products, such as data sets of $\mathrm{H}_{2} \mathrm{O}$ and $\mathrm{NO}_{2}$, will consist of monthly mean averages of GOME-2 products in the netCDF format.

\section{Discussion}

At the time when the first signs of the ozone layer recovery emerge (World Meteorological Organization, 2014), humaninduced air quality problems have become more severe, monitoring of international conventions are established, and environmental security issues, e.g. aviation, are realised to be extremely valuable, the need for long-term quality-monitored $24 / 7$ data services is increasing. The O3M SAF products answer those requests.

The O3M SAF GOME-2 products cover the most important atmospheric constituents and radiation values and thus, the products are used in many operational and scientific applications such as weather forecasting, climatological trend analysis, climate reanalysis, air quality analysis, UV radiation warnings and volcanic emission alerts. The accuracy of the products meets the target requirements and only in special conditions, e.g. in the UTLS or with high SZA, are the requirements not fully met. The data are processed with the state-of-the-art and well-documented algorithms and disseminated via several channels for both NRT as well as offline and data record users. The existing product development and review processes as well as user services ensure direct communication between data experts and users.

The GOME-2 instruments provide a long homogenous data record of 15 years. Furthermore, they continue the data sets started with the earlier instruments, like GOME, and will be followed by the Sentinel 5 instrument onboard the EPSSG (EUMETSAT Polar Satellites - Second Generation) platforms. Overall, the O3M SAF GOME-2 products have an important impact on our knowledge in fields of research and monitoring of the atmosphere. Thus, the potential new users are encouraged to explore the GOME-2 Level 2 data products as well as interact with the product developers.

Acknowledgements. The O3M SAF is part of the EUMETSAT Satellite Application Facility Ground Segment. The project is funded by EUMETSAT and involved national entities. Part of the validation results are based on ground-based data acquired in the framework of the Network for the Detection of Atmospheric Composition Change (NDACC) and are available publicly (see http://ndacc.org). Advanced validation methods were developed under EC FP6 GEOMon and BELSPO/ProDEx SECPEA and A3C projects.

Edited by: R. Munro

\section{References}

Azam, F., Richter, A., Weber, M., Noë, S., and Burrows, J. P.: GOME-2 on MetOp-B Follow-on analysis of GOME2 in orbit degradation, Final Report EUM/CO/09/4600000696/RM, EUMETSAT, availeble at: http://www.eumetsat.int/website/ $\mathrm{wcm} / \mathrm{idc} / \mathrm{idcp} l g$ ?IdcService $=$ GET_FILE $\&$ dDocName $=$ PDF_GOME_DEG_REP\&RevisionSelectionMethod= LatestReleased\&Rendition=Web (last access: 26 January 2016), 2015.

Begoin, M., Richter, A., Weber, M., Kaleschke, L., Tian-Kunze, X., Stohl, A., Theys, N., and Burrows, J. P.: Satellite observations of long range transport of a large $\mathrm{BrO}$ plume in the Arctic, Atmos. Chem. Phys., 10, 6515-6526, doi:10.5194/acp-10-65152010, 2010.

Beirle, S., Kühl, S., Pukite, J., and Wagner, T.: Retrieval of tropospheric column densities of $\mathrm{NO}_{2}$ from combined SCIAMACHY nadir/limb measurements, Atmos. Meas. Tech., 3, 283-299, doi:10.5194/amt-3-283-2010, 2010.

Bertaux, J. L., Megie, G., Widemann, T., Chassefiere, E., Pellinen, R., Kyrölä, E., Korpela, S., and Simon, P.: Monitoring of ozone trend by stellar occultations: The GOMOS instrument, Adv. Space Res., 11, 237-242, 1991.

Boersma, K. F., Eskes, H. J., Veefkind, J. P., Brinksma, E. J., van der A, R. J., Sneep, M., van den Oord, G. H. J., Levelt, P. F., Stammes, P., Gleason, J. F., and Bucsela, E. J.: Near-real time retrieval of tropospheric $\mathrm{NO}_{2}$ from OMI, Atmos. Chem. Phys., 7, 2103-2118, doi:10.5194/acp-7-2103-2007, 2007.

Bovensmann, H., Burrows, J. P., Buchwitz, M., Frerick, J., Noë, S., Rozanov, V. V., Chance, K. V., and Goede, A. P. H.: Satellite observations of long range transport of a large $\mathrm{BrO}$ plume in the Arctic, J. Atmos. Sci., 56, 127-150, 1999.

Braathen, G., Mälkki, A., Staehelin, J., Tamminen, J., and Webb, A.: IGACO-Ozone and UV Radiation Implementation Plan, GAW Report 182, WMO, available at: http://www.igaco-o3. fi/linked/en/IGACO-O3_UV_Implementation_Plan.pdf (last access: 26 January 2016), 2008.

Brenot, H., Theys, N., Clarisse, L., van Geffen, J., van Gent, J., Van Roozendael, M., van der A, R., Hurtmans, D., Coheur, P.-F., Clerbaux, C., Valks, P., Hedelt, P., Prata, F., Rasson, O., Sievers, K., and Zehner, C.: Support to Aviation Control Service (SACS): an online service for near-real-time satellite monitoring of volcanic plumes, Nat. Hazards Earth Syst. Sci., 14, 1099-1123, doi:10.5194/nhess-14-1099-2014, 2014.

Callies, J., Corpaccioli, E., Eisinger, M., Hahne, A., and Lefebvre, A.: GOME-2 - Metop's Second-Generation Sensor for Operational Ozone Monitoring, ESA bulletin, 102, 2000.

Carn, S., Krueger, A., Krotkov, N., Yang, K., and Evans, K.: Tracking volcanic sulfur dioxide clouds for aviation hazard mitigation, Nat. Hazards, 51, 325-343, doi:10.1007/s11069-008-92284, 2009. 
Coldewey-Egbers, M., Slijkhuis, S., Aberle, A., and Loyola, D.: Long-term analysis of GOME in-flight calibration parameters and instrument degradation, Appl. Optics, 47, 4749-4761, 2008.

Dee, D. P., Uppala, S. M., Simmons, A. J., Berrisford, P., Poli, P., Kobayashi, S., Andrae, U., Balmaseda, M. A., Balsamo, G., Bauer, P., Bechtold, P., Beljaars, A. C. M., van de Berg, L., Bidlot, J., Bormann, N., Delsol, C., Dragani, R., Fuentes, M., Geer, A. J., Haimberger, L., Healy, S. B., Hersbach, H., Hólm, E. V., Isaksen, L., Kållberg, P., Köhler, M., Matricardi, M., McNally, A. P., Monge-Sanz, B. M., Morcrette, J.-J., Park, B.-K., Peubey, C., de Rosnay, P., Tavolato, C., Thépaut, J.-N., and Vitart, F.: The ERA-Interim reanalysis: configuration and performance of the data assimilation system, Q. J. Roy. Meteor. Soc., 137, 553-597, doi:10.1002/qj.828, 2011.

De Smedt, I., Van Roozendael, M., Stavrakou, T., Müller, J.-F., Lerot, C., Theys, N., Valks, P., Hao, N., and van der A, R.: Improved retrieval of global tropospheric formaldehyde columns from GOME-2/MetOp-A addressing noise reduction and instrumental degradation issues, Atmos. Meas. Tech., 5, 2933-2949, doi:10.5194/amt-5-2933-2012, 2012.

De Smedt, I., Pinardi, G., Van Roozendael, M., Hao, N., and Valks, P.: Interim verification report of GOME-2 GDP 4.7 HCHO column data for MetOp-B Operational Readiness Review, Technical Note/Validation Report SAF/O3M/IASB/VR/HCHO/113/TNIASB-GOME2B-O3MSAF-HCHO-2013, O3M SAF, available at: http://o3msaf.fmi.fi/docs/vr/Validation_Report_OTO_SO2_ Jun_2013.pdf, 2013.

Dikty, S., Richter, A., M. Weber, S. N., Bovensmann, H., Wittrock, F., and Burrows, J. B.: GOME-2 on MetOp-A Support for Analysis of GOME-2 In-Orbit Degradation and Impacts on Level 2 Data Products Final Report, Technical Document ITT 09/10000262, EUMETSAT, available at: http://www.eumetsat.int/website/wcm/idc/idcplg? IdcService=GET_FILE\&dDocName=PDF_GOME2_MA_ INORB_DEGR_L2_PRODS_REP\&RevisionSelectionMethod= LatestReleased\&Rendition=Web (last access: 26 January 2016), 2011.

Eskes, H., van Velthoven, P., Valks, P., and Kelder, H.: Assimilation of GOME total ozone satellite observations in a threedimensional tracer transport model, Q. J. Roy. Meteor. Soc., 129, 1663-1681, doi:10.1256/qj.02.14, 2003.

EUMETSAT: GOME-2/Metop-A Level 1B Product Validation Report No. 5: Status at Reprocessing G2RP-R2, Technical Document EUM/OPS-EPS/REP/09/0619, version 1F, EUMETSAT, available at: http://www.eumetsat.int/website/wcm/idc/idcplg? IdcService=GET_FILE\&dDocName=pdf_gome_11b_prod_ val\&RevisionSelectionMethod=LatestReleased\&Rendition= Web (last access: 26 January 2016), 2012.

Fischer, H. and Oelhaf, H.: Remote sensing of vertical profiles of atmospheric trace constituents with MIPAS limbemission spectrometers, Appl. Optics, 35, 2787-2796, doi:10.1029/2007JD009505, 1996.

Forster, P., Ramaswamy, V., Artaxo, P., Berntsen, J., Betts, R., Fahey, D. W., Haywood, J., Lean, J., Lowe, D. C., Myhre, G., Nganga, J., Prinn, R., Raga, G., Schulz, M., van Dorland, R., Bodeker, G., Boucher, O., Collins, W. D., Conway, T. J., Dlugokencky, E., Elkins, J. W., Etheridge, D., Foukal, P., Fraser, P., Geller, M., Joos, F., Keeling, C. D., Keeling, R., Kinne, S., Lassey, K., Lohmann, U., Manning, A. C., Montzka, S. A., Oram,
D., O’Shaughnessy, K., Piper, S. C., Plattner, G. K., Ponater, M., Ramankutty, N., Reid, G. C., Rind, D., Rosenlof, K. H., Sausen, R., Schwarzkopf, D., Solanki, S. K., Stenchikov, G., Stuber, N., Takemura, T., Textor, C., Wang, R., Weiss, R., and Whorf, T.: Changes in atmospheric constituents and in radiative forcing, Chap. 2, 129-234, Cambridge University Press, Cambridge, New York, 2007.

Fu, T., Jacob, D. J., Wittrock, F., Burrows, J. P., Vrekoussis, M., and Henze, D. K.: Global budgets of atmospheric glyoxal and methylglyoxal, and implications for formation of secondary organic aerosols, J. Geophys. Res., 113, D15303, doi:10.1029/2007JD009505, 2008.

GCOS: Status of the Global Observing System for Climate, Report GCOS-19, GCOS, available at: https://www.wmo.int/ pages/prog/gcos/Publications/GCOS-195_en_LowRes.pdf (last access: 26 January 2016), 2015.

Grossi, M., Valks, P., Loyola, D., Aberle, B., Slijkhuis, S., Wagner, T., Beirle, S., and Lang, R.: Total column water vapour measurements from GOME-2 MetOp-A and MetOp-B, Atmos. Meas. Tech., 8, 1111-1133, doi:10.5194/amt-8-1111-2015, 2015.

Hallquist, M., Wenger, J. C., Baltensperger, U., Rudich, Y., Simpson, D., Claeys, M., Dommen, J., Donahue, N. M., George, C., Goldstein, A. H., Hamilton, J. F., Herrmann, H., Hoffmann, T., Iinuma, Y., Jang, M., Jenkin, M. E., Jimenez, J. L., Kiendler-Scharr, A., Maenhaut, W., McFiggans, G., Mentel, Th. F., Monod, A., Prévôt, A. S. H., Seinfeld, J. H., Surratt, J. D., Szmigielski, R., and Wildt, J.: The formation, properties and impact of secondary organic aerosol: current and emerging issues, Atmos. Chem. Phys., 9, 5155-5236, doi:10.5194/acp-9-51552009, 2009.

Hao, N., Koukouli, M. E., Inness, A., Valks, P., Loyola, D. G., Zimmer, W., Balis, D. S., Zyrichidou, I., Van Roozendael, M., Lerot, C., and Spurr, R. J. D.: GOME-2 total ozone columns from MetOp-A/MetOp-B and assimilation in the MACC system, Atmos. Meas. Tech., 7, 2937-2951, doi:10.5194/amt-7-2937-2014, 2014.

Heath, D. F., Mateer, C. L., and Krueger, A. J.: The Nimbus-4 Backscatter Ultraviolet (BUV) atmospheric ozone experiment - two years' operation, Pure Appl. Geophys., 106, 1238-1253, 1973.

Heath, D. F., Krueger, A. J., Roeder, H. A., and Henderson, B. D.: The Solar Backscatter Ultraviolet and Total Ozone Mapping Spectrometer (SBUV/TOMS) for NIMBUS G, Opt. Eng., 14, 323-331, doi:10.1117/12.7971839, 1975.

Hegg, D. A. and Baker, M. B.: Nucleation in the atmosphere, Reports on Progress in Physics, 72, 056801, doi:10.1088/0034 4885/72/5/056801, 2009.

Heinen, T., Kiemle, S., Buckl, B., Mikusch, E., and Loyola, D.: The Geospatial Service Infrastructure for DLR's National Remote Sensing Data Library, IEEE Geoscience and Remote Sensing Society, 2, 260-269, doi:10.1109/JSTARS.2010.2040505, 2009.

Hendrick, F., Van Roozendael, M., Chipperfield, M. P., Dorf, M., Goutail, F., Yang, X., Fayt, C., Hermans, C., Pfeilsticker, K., Pommereau, J.-P., Pyle, J. A., Theys, N., and De Mazière, M.: Retrieval of stratospheric and tropospheric $\mathrm{BrO}$ profiles and columns using ground-based zenith-sky DOAS observations at Harestua, $60^{\circ} \mathrm{N}$, Atmos. Chem. Phys., 7, 4869-4885, doi:10.5194/acp-7-4869-2007, 2007. 
Hörmann, C., Sihler, H., Bobrowski, N., Beirle, S., Penning de Vries, M., Platt, U., and Wagner, T.: Systematic investigation of bromine monoxide in volcanic plumes from space by using the GOME-2 instrument, Atmos. Chem. Phys., 13, 4749-4781, doi:10.5194/acp-13-4749-2013, 2013.

JønchSørensen, H.: O3M SAF validation report, NRT UV Index clear sky and cloud corrected, Validation Report SAF/O3M/DMI/VR/NUV/091, O3M SAF, 2012.

Kalakoski, N., Kujanpää, J., Sofieva, V., Tamminen, J., Grossi, M., and Valks, P.: Comparison of GOME-2/Metop total column water vapour with ground-based and in situ measurements, Atmos. Meas. Tech. Discuss., 7, 12517-12543, doi:10.5194/amtd7-12517-2014, 2014

Kauppi, A., Tuinder, O. N. E., Tukiainen, S., Sofieva, V., and Tamminen, J.: Comparison of GOME-2/Metop-A ozone profiles with GOMOS, OSIRIS and MLS measurements, Atmos. Meas. Tech., 9, 249-261, doi:10.5194/amt-9-249-2016, 2016.

Kleipool, O. L., Dobber, M. R., de Haan, J. F., and Levelt, P. F.: Earth surface reflectance climatology from 3 years of OMI data, J. Geophys. Res., 113, D18308, doi:10.1029/2008JD010290, 2008

Koelemeijer, R. B. A., de Haan, J. F., and Stammes, P.: A database of spectral surface reflectivity in the range $335-772 \mathrm{~nm}$ derived from 5.5 years of GOME observations, J. Geophys. Res., 108, 4070, doi:10.1029/2002JD002429, 2003.

Koukouli, M. E., Balis, D. S., Loyola, D., Valks, P., Zimmer, W., Hao, N., Lambert, J.-C., Van Roozendael, M., Lerot, C., and Spurr, R. J. D.: Geophysical validation and long-term consistency between GOME-2/MetOp-A total ozone column and measurements from the sensors GOME/ERS-2, SCIAMACHY/ENVISAT and OMI/Aura, Atmos. Meas. Tech., 5, 2169-2181, doi:10.5194/amt-5-2169-2012, 2012.

Kujanpää, J. and Kalakoski, N.: Operational surface UV radiation product from GOME-2 and AVHRR/3 data, Atmos. Meas. Tech., 8, 4399-4414, doi:10.5194/amt-8-4399-2015, 2015.

Lang, R., Casadio, S., Maurellis, A. N., and Lawrence, M. G.: Evaluation of the GOME Water Vapor Climatology 19952002, J. Geophys. Res.-Atmos., 112, 2156-2202, D17110, doi:10.1029/2006JD008246, 2007.

Lerot, C., Stavrakou, T., De Smedt, I., Müller, J.-F., and Van Roozendael, M.: Glyoxal vertical columns from GOME-2 backscattered light measurements and comparisons with a global model, Atmos. Chem. Phys., 10, 12059-12072, doi:10.5194/acp10-12059-2010, 2010.

Li, C., Joiner, J., Krotkov, N. A., and Bhartia, P. K.: A fast and sensitive new satellite $\mathrm{SO}_{2}$ retrieval algorithm based on principal component analysis: Application to the ozone monitoring instrument, Geophys. Res. Lett., 40, 6314-6318, doi:10.1002/2013GL058134, 2013.

Llewellyn, E. J., Degenstein, D. A., Lloyd, N. D., Gattinger, R. L., Petelina, S., McDade, I. C., Haley, C., Solheim, B. H., von Savigny, C., Sioris, C., Evans, W. F. J., Strong, K., Murtagh, D. P., and Stegman, J.: First results from the OSIRIS instrument on-board Odin, Sodankyla Geophys. Obs. Publ., 92, 41-47, 2003.

Loyola, D., Thomas, W., Livschitz, Y., Ruppert, T., Albert, P., and Hollmann, R.: Cloud properties derived from GOME/ERS-2 backscatter data for trace gas retrieval, IEEE T. Geosci. Remote Sens., 45, 2747-2758, doi:10.1109/TGRS.2007.901043, 2007.
Loyola, D. G., Koukouli, M. E., Valks, P., Balis, D. S., Hao, N., Van Roozendael, M., Spurr, R. J. D., Zimmer, W., Kiemle, S., Lerot, C., and Lambert, J.-C.: The GOME-2 total column ozone product: Retrieval algorithm and ground-based validation, J. Geophys. Res., 116, D07302, doi:10.1029/2010JD014675, 2011.

Lutz, R., Loyola, D., Gimeno García, S., and Romahn, F.: OCRA radiometric cloud fractions for GOME-2 on MetOp-A/B, Atmos. Meas. Tech. Discuss., 8, 13471-13524, doi:10.5194/amtd8-13471-2015, 2015.

Malicet, J., Daumont, D., Charbonnier, J., Parisse, C., Chakir, A., and Brion, J.: Ozone UV spectroscopy. II. Absorption crosssections and temperature dependence, J. Atmos. Chem., 21, 263 273, doi:10.1007/BF00696758, 1995.

McCormic, M. P., Thomason, L. W., and Trepte, C. R.: Atmospheric effects of the Mount Pinatubo eruption, Nature, 373, 399-404, doi:10.1038/373399a0, 1995.

Mieruch, S., Schröder, M., Noël, S., and Schultz, J.: Comparison of monthly means of global total column water vapor retrieved from independent satellite observations, J. Geophys. Res., 115, D23310, doi:10.1029/2010JD013946, 2010

Munro, R., Eisinger, M., Anderson, C., Callies, J., Corpaccioli, E., Lang, R., Lefebvre, A., Livschitz, Y., and Albiñana, A. P. GOME-2 on MetOp, in: Proc. of the 2006 EUMETSAT Meteorological Satellite Conference, Helsinki, Finland, p. 48, EUMETSAT, 2006.

Munro, R., Lang, R., Klaes, D., Poli, G., Retscher, C., Lindstrot, R., Huckle, R., Lacan, A., Grzegorski, M., Holdak, A., Kokhanovsky, A., Livschitz, J., and Eisinger, M.: The GOME2 instrument on the Metop series of satellites: instrument design, calibration, and level 1 data processing - an overview, Atmos. Meas. Tech. Discuss., 8, 8645-8700, doi:10.5194/amtd-8-86452015, 2015.

Noël, S., Mieruch, S., Bovensmann, H., and Burrows, J. P.: Preliminary results of GOME-2 water vapour retrievals and first applications in polar regions, Atmos. Chem. Phys., 8, 1519-1529, doi:10.5194/acp-8-1519-2008, 2008.

Pinardi, G., Lambert, J.-C., Granville, J., Yu, H., De Smedt, I., Van Roozendael, M., and Valks, P.: Interim verification report of GOME-2 GDP 4.7 NO2 column data for MetOp-B Operational Readiness Review, Technical Note/Validation Report SAF/O3M/IASB/VR/NO2/095/TN-IASB-GOME2B-O3MSAFNO2-2013), O3M SAF, 2013.

Pinardi, G., Van Roozendael, M., Lambert, J.-C., Granville, J., Hendrick, F., Tack, F., Yu, H., Cede, A., Kanaya, Y., Irie, I., Goutail, F., Pommereau, J.-P., Pazmino, A., Wittrock, F., Richter, A., Wagner, T., Gu, M., Remmers, J., Friess, U., Vlemmix, T., Piters, A., Hao, N., Tiefengraber, M., Herman, J., Abuhassan, N., Bais, A., Kouremeti, N., Hovila, J., Holla, R., Chong, J., Postylyakov, O., and Ma, J.: GOME-2 total and tropospheric $\mathrm{NO}_{2}$ validation based on zenith-sky, direct-sun and multi-axis DOAS network observations, in: Proc. of the 2014 EUMETSAT Meteorological Satellite Conference, Geneva, Swizerland, EUMETSAT, 2014.

Platt, U. and Stutz, J.: Differential Optical Absorption Spectroscopy: Principles and Applications (Physics of Earth and Space Environments), Springer-Verlag, 2008.

Richter, A.: S5P/TROPOMI Draft Scientific Verification Report, Technical Note/Validation Report S5P-IUP-L2-ScVR-RP), IUP, 2015 . 
Richter, A. and Burrows, J.: Tropospheric $\mathrm{NO}_{2}$ from GOME measurements, Adv. Space Res., 29, 1673-1683, 2002.

Richter, A., Wittrock, F., Ladstäatter-Weißenmayer, A., and Burrows, J. P.: GOME measurements of stratospheric and tropospheric BrO, Adv. Space Res., 29, 1667-1672, 2002.

Richter, A., Begoin, M., Hilboll, A., and Burrows, J. P.: An improved $\mathrm{NO}_{2}$ retrieval for the GOME-2 satellite instrument, Atmos. Meas. Tech., 4, 1147-1159, doi:10.5194/amt-4-1147-2011, 2011.

Rix, M., Valks, P., Hao, N., van Geffen, J., Clerbaux, C., Clarisse, C., Coheur, P.-F., Loyola, D., Erbertseder, T., Zimmer, W., and Emmadi, S.: Satellite Monitoring of Volcanic Sulfur Dioxide Emissions for Early Warning of Volcanic Hazards, IEEE J. Sel. Top. Appl., 2, 196-206, doi:10.1109/JSTARS.2009.2031120, 2009.

Rix, M., Valks, P., Hao, N., Loyola, D., Schlager, H., Huntrieser, H., Flemming, J., Koehler, U., Schumann, U., and Inness, A.: Volcanic $\mathrm{SO}_{2}, \mathrm{BrO}$ and plume height estimations using GOME-2 satellite measurements during the eruption of Eyjafjallajökull in May 2010, J. Geophys. Res., 117, D00U19, doi:10.1029/2011JD016718, 2012.

Robock, A.: Volcanic eruptions and climate, Rev. Geophys., 38, 191-219, doi:10.1029/1998RG000054, 2000.

Salawitch, R. J., Canty, T., Kurosu, T., Chance, K., Liang, Q., da Silva, A., Pawson, S., Nielsen, J. E., Rodriguez, J. M., Bhartia, P. K., Liu, X., Huey, L. G., Liao, J., Stickel, R. E., Tanner, D. J., Dibb, J. E., Simpson, W. R., Donohoue, D., Weinheimer, A., Flocke, F., Knapp, D., Montzka, D., Neuman, J. A., Nowak, J. B., Ryerson, T. B., Oltmans, S., Blake, D. R., Atlas, E. L., Kinnison, D. E., Tilmes, S., Pan, L. L., Hendrick, F., Van Roozendael, M., Kreher, K., Johnston, P. V., Gao, R. S., Johnson, B., Bui, T. P., Chen, G., Pierce, R. B., Crawford, J. H., and Jacob, D. J.: A new interpretation of total column $\mathrm{BrO}$ during Arctic spring, Geophys. Res. Lett., 37, L21805, doi:10.1029/2010GL043798, 2010.

Solomon, S., Rosenlof, K. H., Portmann, R. W., Daniel, J. S., Davis, S. M., Sanford, T. J., and Plattner, G.-K.: Contributions of Stratospheric Water Vapor to Decadal Changes in the Rate of Global Warming, Science, 327, 1219-1223, doi:10.1126/science.1182488, 2000.

Stavrakou, T., Müller, J.-F., De Smedt, I., Van Roozendael, M., Kanakidou, M., Vrekoussis, M., Wittrock, F., Richter, A., and Burrows, J. P.: The continental source of glyoxal estimated by the synergistic use of spaceborne measurements and inverse modelling, Atmos. Chem. Phys., 9, 8431-8446, doi:10.5194/acp-98431-2009, 2009.

Theys, N., Van Roozendael, M., Dils, B., Hendrick, F., Hao, N., and De Maziére, M.: First satellite detection of volcanic bromine monoxide emission after the Kasatochi eruption, Geophys. Res. Lett., 36, L03809, doi:10.1029/2008GL036552, 2009a.

Theys, N., Van Roozendael, M., Errera, Q., Hendrick, F., Daerden, F., Chabrillat, S., Dorf, M., Pfeilsticker, K., Rozanov, A., Lotz, W., Burrows, J. P., Lambert, J.-C., Goutail, F., Roscoe, H. K., and De Mazière, M.: A global stratospheric bromine monoxide climatology based on the BASCOE chemical transport model, Atmos. Chem. Phys., 9, 831-848, doi:10.5194/acp-9-831-2009, 2009 b.

Theys, N., Van Roozendael, M., Hendrick, F., Yang, X., De Smedt, I., Richter, A., Begoin, M., Errera, Q., Johnston, P. V., Kreher, K., and De Mazière, M.: Global observations of tropospheric BrO columns using GOME-2 satellite data, Atmos. Chem. Phys., 11, 1791-1811, doi:10.5194/acp-11-1791-2011, 2011.

Theys, N., Hendrick, F., van Roozendael, M., N. Hao, N., and Valks, P.: Interim verification report of GOME-2 GDP 4.7 BrO column data for MetOp-B Operational Readiness Review, Technical Note/Validation Report SAF/O3M/IASB/VR/BRO/091/TNIASB-GOME2B-O3MSAF-BRO-2013), O3M SAF, available at: http://o3msaf.fmi.fi/docs/vr/Validation_Report_OTO_BRO_ Jun_2013.pdf (last access: 26 January 2016), 2013a.

Theys, N., Van Gent, J., van Roozendael, M., Koukouli, M., Balis, D., Hedelt, P., and Valks, P.: Interim verification report of GOME-2 GDP 4.7 SO2 column data for MetOp-B Operational Readiness Review, Technical Note/Validation Report SAF/O3M/IASB/VR/SO2/TN-IASB-GOME2B-O3MSAFSO2-2013), O3M SAF, available at: http://o3msaf.fmi.fi/docs/ vr/Validation_Report_OTO_SO2_May_2013.pdf (last access: 26 January 2016), 2013b.

Tilstra, L. G., Tuinder, O. N. E., and Stammes, P.: GOME-2 Absorbing Aerosol Index: Statistical analysis, comparison to GOME1 and impact of instrument degradation, in: Proceedings of the 2010 EUMETSAT Meteorological Satellite Conference, p. 57, EUMETSAT, iSBN 978-92-9110-089-7, 2010.

Tilstra, L. G., de Graaf, M., Aben, I., and Stammes, P.: In-flight degradation correction of SCIAMACHY UV reflectances and Absorbing Aerosol Index, J. Geophys. Res., 117, D06209, 21562202, doi:10.1029/2011JD016957, 2012a.

Tilstra, L. G., Tuinder, O. N. E., and Stammes, P.: A new method for in-flight degradation correction of GOME-2 Earth reflectance measurements, with application to the Absorbing Aerosol Index, Proceedings of the 2012 EUMETSAT Meteorological Satellite Conference, p. 61, 2012b.

Tilstra, L. G., Tuinder, O. N. E., and Stammes, P.: O3M SAF Validation Report for Aerosol Products, Technical Note/Validation Report SAF/O3M/KNMI/VR/001), O3M SAF, available at: http://o3msaf.fmi.fi/docs/vr/Validation_Report_ARS_AAI_Jun_ 2013.pdf (last access: 26 January 2016), 2013.

Tilstra, L. G., Tuinder, O. N. E., and Stammes, P.: GOME-2 surface LER product - Algorithm Theoretical Basis Document, Atbd, O3M SAF, available at: http://o3msaf.fmi.fi/docs/atbd/ Algorithm_Theoretical_Basis_Document_LER_Nov_2014.pdf (last access: 26 January 2016), 2014.

Valks, P., Pinardi, G., Richter, A., Lambert, J.-C., Hao, N., Loyola, D., Van Roozendael, M., and Emmadi, S.: Operational total and tropospheric $\mathrm{NO}_{2}$ column retrieval for GOME-2, Atmos. Meas. Tech., 4, 1491-1514, doi:10.5194/amt-4-1491-2011, 2011.

Valks, P., Hao, N., Gimeno Garcia, S., Loyola, D., Dameris, M., Jöckel, P., and Delcloo, A.: Tropical tropospheric ozone column retrieval for GOME-2, Atmos. Meas. Tech., 7, 2513-2530, doi:10.5194/amt-7-2513-2014, 2014.

van Peet, J. C. A., van $\operatorname{der}$ A, R. J., de Laat, A. T. J., Tuinder, O. N. E., König-Langlo, G., and Wittig, J.: Height resolved ozone hole structure as observed by the Global Ozone Monitoring Experiment-2, Geophys. Res. Lett., 36, L11816, doi:10.1029/2009GL038603, 2009.

van Peet, J. C. A., van der A, R. J., Tuinder, O. N. E., Wolfram, E., Salvador, J., Levelt, P. F., and Kelder, H. M.: Ozone ProfilE Retrieval Algorithm (OPERA) for nadir-looking satellite 
instruments in the UV-VIS, Atmos. Meas. Tech., 7, 859-876, doi:10.5194/amt-7-859-2014, 2014.

Van Roozendael, M., Loyola, D., Spurr, R., Balis, D., Lambert, J.-C., Livschitz, Y., Valks, P., Ruppert, T., Kenter, P., Fayt, C., and Zehner, C.: Ten years of GOME/ERS-2 total ozone data-The new GOME data processor (GDP) version 4: 1. Algorithm description, J. Geophys. Res., 111, D07307, doi:10.1029/2005JD006375, 2006.

Vrekoussis, M., Wittrock, F., Richter, A., and Burrows, J. P.: GOME-2 observations of oxygenated VOCs: what can we learn from the ratio glyoxal to formaldehyde on a global scale?, Atmos. Chem. Phys., 10, 10145-10160, doi:10.5194/acp-1010145-2010, 2010.

Wagner, T., Beirle, S., Grzegorski, M., and Platt, U.: Global trends (1996-2003) of total column precipitable water observed by Global Ozone Monitoring Experiment (GOME) on ERS-2 and their relation to near-surface temperature, J. Geophys. Res., 111, D12102, doi:10.1029/2005JD006523, 2006.

Wang, P., Stammes, P., van der A, R., Pinardi, G., and van Roozendael, M.: FRESCO+: an improved O2 A-band cloud retrieval algorithm for tropospheric trace gas retrievals, Atmos. Chem. Phys., 8, 6565-6576, doi:10.5194/acp-8-6565-2008, 2008.
Wang, P., Tuinder, O. N. E., Tilstra, L. G., de Graaf, M., and Stammes, P.: Interpretation of FRESCO cloud retrievals in case of absorbing aerosol events, Atmos. Chem. Phys., 12, 90579077, doi:10.5194/acp-12-9057-2012, 2012.

Wenig, M., Kuhl, S., Beirle, S., Bucsela, E., Jahne, B., Platt, U., Gleason, J., and Wagner, T.: Retrieval and analysis of stratospheric $\mathrm{NO}_{2}$ from the Global Ozone Monitoring Experiment, J. Geophys. Res., 109, D04315, doi:10.1029/2003JD003652, 2004.

Wentz, F. J. and Meissner, T.: AMSR-E Ocean Algorithms; Supplement 1, Report 051707, Remote Sensing Systems, Santa Rosa, CA, 2007.

Wittrock, F., Richter, A., Oetjen, H., Burrows, J. P., Kanakidou, M., Myriokefalitakis, S., Volkamer, R., Beirle, S., Platt, U., and Wagner, T.: Simultaneous global observations of glyoxal and formaldehyde from space, Geophys. Res. Lett., 33, L16804, doi:10.1029/2006GL026310, 2006.

World Meteorological Organization: Scientific Assessment of Ozone Depletion: 2014, Global Ozone Research and Monitoring Project - Report No. 56, Geneva, Switzerland, 2014. 